\title{
El Cancionero musical de Gerona: madrigales y villancicos en una nueva fuente hispánica del siglo XVI
}

\section{The Cancionero musical de Gerona: madrigals and villancicos in a new Hispanic source from the 16th century}

\section{Francesc Villanueva Serrano \\ Investigador independiente fvilanue@hotmail.com} ORCID iD: https://orcid.org/ 0000-0002-4680-1546

\section{RESUMEN}

Son muy escasos los ejemplos que han llegado hasta nuestros días del repertorio profano en castellano que se compuso y practicó en la península ibérica durante la segunda mitad del siglo XVI, fundamentalmente constituido por villancicos y madrigales. En este artículo se presenta una nueva fuente musical incompleta de este repertorio localizada en el Arxiu Històric de Girona. Se trata de un librete de parte individual que contiene 13 madrigales, 8 villancicos, 1 villanesca napolitana y otra pieza incompleta no clasificable, entre los que se cuentan dieciete unica. El manuscrito atribuye algunas autorías musicales a Nicasi Sorita, Pedro Ortega y Francisco Guerrero. Las concordancias en otras fuentes permiten añadir en esta lista a Pedro Guerrero, Juan Navarro y Roger Pathie o Adrian Willaert. Los poemas musicados identificados pertenecen a Garcilaso de la Vega, Juan Boscán, Jorge de Montemayor y Pêro de Andrade Caminha.

Palabras clave: Cancionero, Gerona, villancicos, madrigales, Sorita. 


\begin{abstract}
There are very few examples that have survived of the secular Spanish repertoire that was composed and practiced in the Iberian Peninsula during the second half of the 16th century. This corpus is mainly made up of villancicos and madrigals. This article presents a new incomplete musical source of this repertoire located in the Arxiu Històric de Girona. It is an individual part booklet that contains 13 madrigals, 8 villancicos 1 Neapolitan villanesca and another piece that cannot be classified, seventeen of them being unica. The manuscript attributes some musical authorship to Nicasi Sorita, Pedro Ortega and Francisco Guerrero. The musical concordances in other sources allow adding in this list Pedro Guerrero, Juan Navarro and Roger Pathie or Adrian Willaert. . The identified poems belong to Garcilaso de la Vega, Juan Boscán, Jorge de Montemayor and Pêro de Andrade Caminha.
\end{abstract}

Key Words: Songbook, Girona, villancicos, madrigals, Sorita.

Villanueva Serrano, F. (2022). El Cancionero musical de Gerona: madrigales y villancicos en una nueva fuente hispánica del siglo XVI. Cuadernos de Investigación Musical, (14), pp. 67-114.

\title{
1. INTRODUCCIÓN
}

La publicación en 1543 de Las obras de Boscán y algunas de Garcilaso de la Vega repartidas en quatro libros en la imprenta barcelonesa de Carles Amorós posibilitó por primera vez la difusión a gran escala en la península ibérica de una nueva lírica en castellano que usaba los moldes de la poesía italiana de corte petrarquista ${ }^{1}$. El mismo Juan Boscán (*1487-1492; †1542) declaraba haber sido su introductor a partir de 1526 tras atender a los ruegos del embajador veneciano Andrea Navagero de intentar tal adaptación (Boscán, 1999, pp. 118120), aunque fue su amigo Garcilaso de la Vega (*1499; †1536) quien la elevó hasta las más altas cotas. El citado impreso con las obras de ambos autores obtuvo un extraordinario éxito editorial. Solo en los quince años que siguieron a la edición príncipe se estamparon al menos dieciséis reediciones no solo en territorio ibérico sino también en Amberes, Roma, París y Lyon ${ }^{2}$. Las formas poéticas basadas en los versos endecasílabos, como los sonetos o las octavas reales, y los heptasílabos se extendieron rápidamente entre los autores hispanos. A pesar de ello, la irrupción de estas novedades italianizantes no significó la desaparición de los géneros tradicionales castellanos, fundamentalmente los villancicos, sino que ambas corrientes poéticas convivieron largo tiempo.

\footnotetext{
${ }^{1}$ Edición moderna de las obras de este impreso en Boscán, 1999; De la Vega, 2004.

${ }^{2}$ La relación completa de estas reediciones en Boscán, 1999, pp. 25-26. 


\section{El CANCIONERO MUSICAL DE GERONA: MADRIGALES Y VILLANCICOS EN UNA NUEVA FUENTE HISPÁNICA DEL SIGLO XVI}

Junto a los nuevos géneros y metros de la poesía italiana llegó a la península la forma musical del madrigal, que se adaptaba perfectamente a las nuevas composiciones poéticas. Desde un principio, el madrigal hispánico del siglo XVI adoptó de su antecedente italiano la composición de nueva música para cada verso del texto y el uso del verso endecasílabo. Estos planteamientos contrastaban con el de los villancicos y romances castellanos, formas estróficas divididas en dos secciones musicales que se repetían y estaban construidas fundamentalmente con versos octosílabos o hexasílabos ${ }^{3}$. Los cuatro ejemplos más tempranos conocidos de madrigales en castellano aparecieron en el impreso Villancicos $i$ canciones, a tres y a quatro de Juan Vázquez (Vázquez, 1551).

Tras esta publicación, al menos una decena de libros que contenían villancicos y/o madrigales, profanos y religiosos, vieron la luz hasta el año $1624^{5}$. Este año se imprimió el último libro conocido con madrigales castellanos, paradójicamente compuestos por un autor italiano - Stefano Limido- y también el último con villancicos, que llevó a la imprenta Juan Arañés en Roma. No obstante, estos últimos villancicos están ya emparentados con los denominados tonos humanos, surgidos de los cambios operados en los géneros poéticos castellanos a partir de la década de 1580 por obra de la generación literaria de Lope de Vega (*1562; †1635) (Etzion, 1996, pp. xxxv-lx; Cerveró Martínez, 2017, pp. 219-298) ${ }^{6}$. No en vano, tras el segundo impreso de Juan Vázquez, titulado Recopilación de sonetos y villancicos a quatro y a cinco (1560), el villancico polifónico profano del Renacimiento ya no volvió a recibir la atención de la imprenta aunque no dejó de practicarse durante las siguientes décadas. En un puñado de manuscritos conservados de esta época, los villancicos se hallan habitualmente junto a los madrigales, lo cual es un testimonio y un reflejo de esa dualidad de géneros que dominó el repertorio polifónico profano.

El más relevante de estos manuscritos es, sin duda, el denominado Cancionero Musical de la Casa de Medinaceli (CMM), datado en torno a 1569 y vinculado probablemente a este linaje nobiliario, que recoge la música completa de más de un centenar de estas piezas junto a otras litúrgicas ${ }^{7}$. De otro lado, el Cancioneiro Musical de Belém, compilado seguramente en

\footnotetext{
${ }^{3}$ En lo sucesivo, se adoptará el criterio de Margarita Restrepo para la consideración de una pieza musical en castellano como "madrigal" ("through-composed forms and of hendecasyllabic verse"), "villancico" ("marked by a refrain that alternated with one or more strophes") o "romance" ("a long narrative poem of many verses") (Restrepo, 2009, vol. I p. 11). No obstante, se trata de una clasificación moderna simplificada a efectos prácticos que se empleará aquí ante la falta de unanimidad terminológica entre los autores de la época (Gómez Gallego, 2015, vol. I, pp. 258-261).

4 Ediciones en: Vásquez, 1995; Gómez Gallego, 2015, vol. II, pp. 41-167. La relación de las piezas consideradas madrigales en Restrepo, 2009, vol. I, p. 346.

${ }^{5}$ Cancionero de Uppsala o Cancionero del Duque de Calabria (Varios, 1556); ediciones en: Bal y Gay, 1944; Querol Rosso, 1980; Riosalido, 1983; Bornstein, 1998; y Gómez Muntané, 2003. Vázquez, 1560; edición en Anglés, 1946. Alberch Vila, 1560; incompleto (solo “alto”). Alberch Vila, 1561; incompleto (solo "alto”). Brudieu, 1585; edición en Pedrell \& Anglés, 1921. Guerrero, 1589; edición en Querol Gavaldá \& García Julbe, 1955 y 1957. Limido, 1605; incompleto (solo “canto”). Ruimonte, 1614; edición en Calahorra Martínez, 1980. Limido, 1624; sin edición completa; algunos de sus madrigales en Iglesias, 1992; Villanueva Serrano, 2019, pp. 321-328. Arañés, 1624; edición en Cerveró Martínez, 2017. Quizá en 1554 se imprimiese el libro Sonetos y madrigales difíciles a 3 de Pedro Guerrero, del que no se conoce actualmente ningún ejemplar (Iglesias, 1998). En esta relación no se incluyen las versiones instrumentales para vihuela o para canto y vihuela.

${ }^{6}$ Una relación de fuentes de tonos humanos, con indicación de las ediciones modernas disponibles, en Etzion, 1996, p. xxi, nota 7.

${ }^{7}$ E-PAbm, B99-V2-22 [olim Madrid 13230 o R. 6829/861]. Edición completa en Querol Gavaldá, 1949-1950.
} 


\section{FraNCESC VilLANUEVA SERRANO}

Oporto en 1603, aunque con un repertorio compuesto seguramente entre 1550 y 1580, también conserva la música íntegra de diecisiete obras castellanas y una portuguesa (LeeFrancis Askins \& Sage, 1976) ${ }^{8}$. Por su parte, el llamado Cancioneiro Musical de Elvas, contiene solo cinco piezas completas de la segunda mitad del siglo XVI, siendo el resto de composición anterior'. Por último, el manuscrito 975 del Archivo Manuel de Falla de Granada contiene algunas piezas con títulos castellanos pero sin texto, por lo que se considera un libro de ministriles (Christoforidis \& Ruiz Jiménez, 1994) ${ }^{10}$. Todos los manuscritos anteriores tienen en común su formato en libro de facistol, que ha hecho posible la conservación íntegra de todas las partes musicales.

A diferencia de estos, otras tres fuentes en formato de libretes individuales se han preservado desafortunadamente incompletas por el extravío de parte de estos. Es el caso del Cancionero Musical del Museo Lázaro Galdiano (CMLG) de Madrid que, según Alejandro Luis Iglesias, podría datarse en el último cuarto del siglo XVI, del que se conserva únicamente la parte de tiple de una colección de cincuenta y cinco obras castellanas (Iglesias, 1996) ${ }^{11}$. Asimismo, los dos únicos cuadernos preservados de cantus y altus del denominado Cancionero Musical Valenciano (CMV), datado estimativamente en el período 1560-1582, transmiten dieciocho villancicos castellanos y tres en catalán, además de obras litúrgicas (Frenk, 1992; Goméz Muntané, 2011) ${ }^{12}$. Del manuscrito 17 de la catedral de Valladolid (V17) resta únicamente el librete de tenor, que contiene veintidós piezas castellanas y una en catalán, entre un gran número de italianas y francesas e, incluso, algunas litúrgicas (Anglés, 1948, pp. 83-86; López-Calo, 2008, pp. 184-206) ${ }^{13}$.

A este pequeño grupo de manuscritos incompletos hay que añadir ahora una nueva fuente no referida ni descrita en la bibliografía existente que se conserva en el Arxiu Històric de Girona (Cataluña, España). El objeto del presente artículo será la descripción preliminar y la discusión del posible uso de este pequeño cancionero. En adelante me referiré a él como Cancionero Musical de Gerona (CMG).

\section{DESCRIPCIÓN}

El CMG está inventariado en la serie Manuscrits del Arxiu Històric de Girona con la signatura 34 (E-Gah, ms. 34). Se trata de un librete individual en papel apaisado en $4^{\circ}$ con dimensiones medias aproximadas de $159 \mathrm{~mm}$ x $223 \mathrm{~mm}$, existiendo diferencias de unos pocos milímetros en la anchura de los folios.

\footnotetext{
8 P-Lma, ms. 3391. Edición completa en Morais, 1988.

9 P-Em, 11793. El resto de obras, castellanas y portuguesas, presentan numerosas concordancias con fuentes de la primera mitad de siglo. Ediciones en: Joaquim, 1940; Morais, 1977; Miranda, 1987. Facsímil en Ferreira, 1989.

10 E-GRmf, ms. 975. Cinco de estas piezas atribuidas a Francisco Guerrero han sido publicadas en Ruiz Jiménez, 1999.

11 E-Mlg, Inventario 15411. Iglesias razona que el año de 1548 que figura en el propio manuscrito no concuerda con circunstancias objetivas de algunas obras contenidas.

12 E-Mn, MC3876/34-35. Respecto a la datación, Gómez opina que algunas de las piezas litúrgicas se debieron añadir con posterioridad.

${ }^{13}$ E-V, ms. 17.
} 


\section{EL CANCIONERO MUSICAL DE GERONA:}

Está encuadernado con un bifolio de pergamino reutilizado de un libro litúrgico que contiene notación musical de canto llano sobre tetragrama, cuyas dimensiones son $159 \mathrm{~mm}$ x $221 \mathrm{~mm}$ (tapa anterior) $/ 215 \mathrm{~mm}$ (tapa posterior). La notación musical del pergamino solo es legible en sus dos caras internas. La cara interna anterior contiene diversos versos del canto para la procesión de la benedicción de los santos crismas $O$ Redemptor, mientras que la cara interna posterior contiene parte de Gradual, el Ofertorio y la Comunión de la misa del Jueves Santo. Esta encuadernación no presenta inscripciones adicionales salvo la signatura del manuscrito, escrita sobre una etiqueta moderna adherida en el verso de la tapa anterior.

Consta el CMG de seis bifolios (12 folios), aunque el último folio está mutilado y solamente se conserva su mitad interior (ver apéndice 1). Los bifolios están organizados en dos fascículos: un cuaternión (fascículo 1) y un binión (fascículo 2). Están cosidos con la encuadernación mediante un cordel con cuatro puntos de cosido. Todos los folios están escritos por ambas caras.

El CMG no posee una foliación general, por lo que se ha adoptado a efectos de este estudio una foliación consecutiva que, por no estar explícita en el propio manuscrito, se referirá en adelante entre corchetes. Solo los folios completos del binión (ff. [9]-[11]) presentan una paginación particular que va del 5 al 10 en números arábigos la cual, aparentemente, es de la misma mano que su contenido (ver ápendice 1); no obstante, esta paginación no coincide con la que correspondería al manuscrito en su totalidad, ni siquiera al fascículo 2 en que se encuentra. Probablemente también el f. [12], perteneciente al mismo fascículo, estuviese paginado pero no es posible confirmarlo debido a su mutilación.

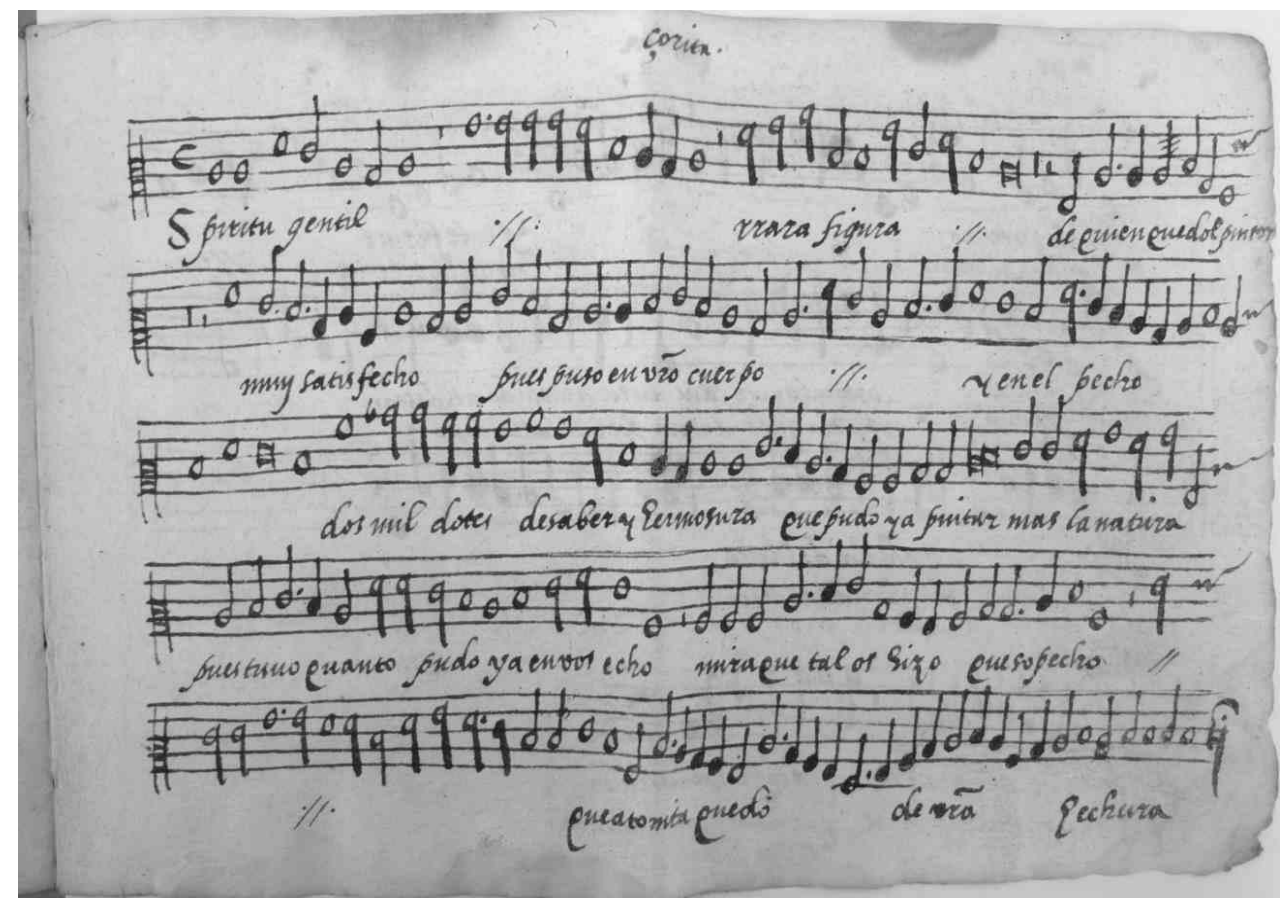

Fig. 1: Cancionero Musical de Gerona.

(E-Gah, ms. 34, f. [4r]). 


\section{FraNCESC VilLANUEVA SERRANO}

La presentación del CMG es muy sencilla, tanto por lo que se refiere al texto como a la música. La caligrafía cursiva del texto y la notación musical se corresponden con la segunda mitad del siglo XVI o primeras décadas del XVII. El único color de tinta usado en el manuscrito es el negro. Las letras capitales en los ff. [1v], [6r], [6v], [7r], [7v], [8r] y [8v] son realzadas sin que ello pueda considerarse una ornamentación elaborada (ver apéndice 2). El manuscrito fue en algún momento plegado por la mitad, por lo cual todos los folios presentan una doblez. En los ff. [1], [2], [7], [8], la tinta ha perforado el papel provocando la pérdida de algunos fragmentos de notación musical, aunque no de texto (ver apéndice 2). No se aprecia suciedad específica en las zonas del paso de folio que sugieran un uso intensivo de todo o de parte del manuscrito.

Únicamente se identifica con claridad un tipo de filigrana, presente en los ff. [3], [4], [8], [9] denominada del Peregrino por Charles-Moïsse Briquet (ver apéndice 1). Se caracteriza por la representación, inscrito dentro de un círculo, de un hombre con sombrero portando un largo báculo (Briquet, 1985, vol. 2, pp. 415-416). Se presenta siempre por mitades (superior o inferior) en el borde inferior o superior de los folios, como corresponde a su formato en $4^{\circ}$ apaisado. Las 45 filigranas de este tipo registradas por Briquet ( $\mathrm{n}^{\circ} 7563-7607$ ) son fundamentalmente de procedencia italiana o del sur de Francia cubriendo el período 1545-1607, aunque en especial abundan en las décadas 1560-1590 (Briquet, 1985, vol. 2, pp. 415-416). Oriol Valls demostró el amplio uso de papel con este tipo de filigrana durante todo el siglo XVI en Cataluña, donde incluso se fabricaba en 1557 (Valls, 1965; Valls, 1970, vol. I, pp. 180-181, 397). No obstante, esta filigrana se ha hallado posteriormente en otros lugares de la península ibérica como Córdoba, Valencia o Santiago de Compostela, también entre 1560 y 1590 (Baena Fernández, García Morales y Najar Torres, 2009, p. 47; González García, 2014, p. 243; Basanta Campos, 1996, vol. I, p. 375). En el f. [4] del CMG la filigrana incluye una cruz sobre el círculo del peregrino y en, al menos, el f. [9] existen un par de letras mayúsculas ("IM") bajo el mismo (ver figs. 2 y 3). Ambos elementos son comunes en este tipo de filigrana aunque debe reseñarse el hecho de que, en las filigranas catalanas posteriores a 1560 localizadas por Valls, dejan de figurar las letras y aparecen las cruces ${ }^{14}$.

${ }^{14} \mathrm{n}^{\mathrm{o}}$ 1588-1602; con cruz, no1597-1601 (Valls, 1970, vol. II, pp. 231-232). 
El CANCIONERO MUSICAL DE GERONA:

MADRIGALES Y VILLANCICOS EN UNA NUEVA FUENTE HISPÁNICA DEL SIGLO XVI

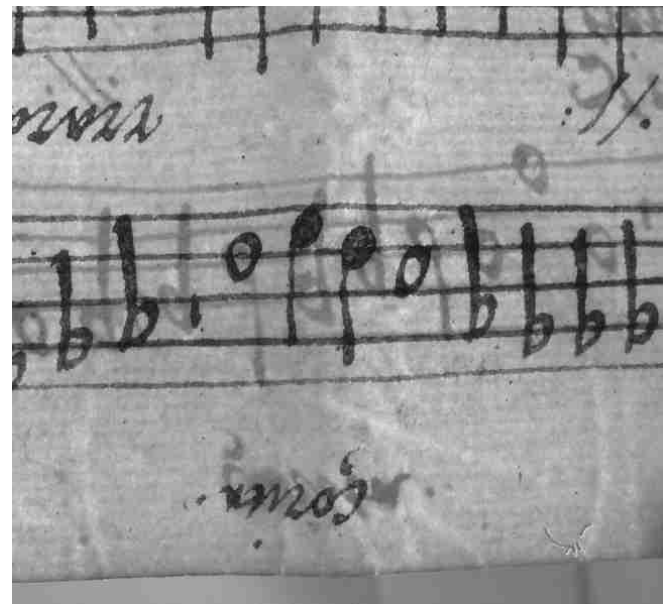

Fig. 2: Filigrana de peregrino con cruz (mitad superior).

(E-Gah, ms. 34, f. [4r]).

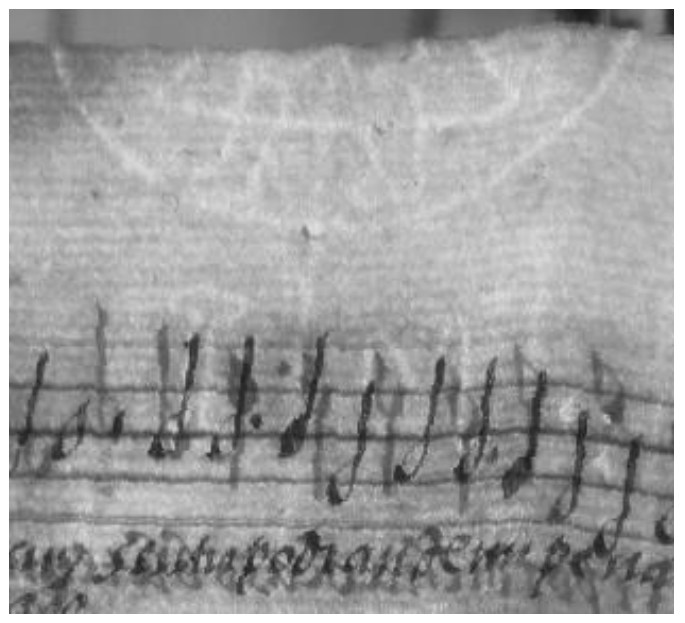

Fig. 3: Filigrana de peregrino con letras (mitad inferior).

(E-Gah, ms. 34, f. [9r]).

De otro lado, en el f. [7] existe media filigrana de difícil identificación, que podría ser la mitad superior de un ejemplar del tipo Mano con flor (ver fig. 4) consistente en una mano extendida con los dedos cerrados. En este tipo de filigranas, del dedo corazón surge un tallo sin hojas de una flor con un botón central circundado por pétalos. Se trata de un grupo de filigranas ampliamente difundido en Europa Occidental. Briquet registró más de un centenar de ellas (n¹1151-11251) en gran número de ciudades europeas durante el período 1470-1598 (Briquet, 1985, vol. 3, pp. 567-570). Valls las localizó en Cataluña desde 1336 a $1530^{15}$. El bifolio que podría presentar esta filigrana (ff. [2] y [7]), es precisamente el más afectado por perforación a causa de la tinta.

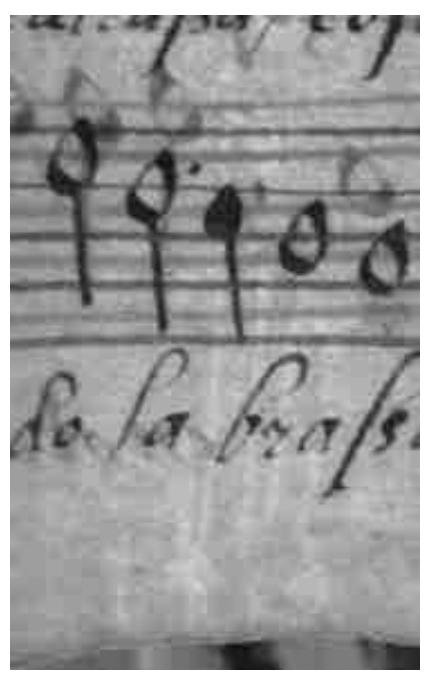

Fig. 4: Filigrana de mano con flor?

(E-Gah, ms. 34, f. [7r]).

${ }^{15}$ no 1653-1657, 1662, 1664, 1666-1668, 1670, 1672 (Valls, 1970, vol. I, pp. 404-405). 


\section{FranCESC VillanUEVA SERRANo}

Se identifican cuatro copistas diferentes en la escritura del manuscrito, que hemos denominado A, B, C, D (ver apéndices 1 y 2). A y B trabajaron en el fascículo 1, mientras que $\mathrm{C}$ y $\mathrm{D}$ lo hicieron en el fascículo 2, aunque la participación de este último se limita únicamente a dos pentagramas en la última página del manuscrito. Los escribanos $\mathrm{A}$ y $\mathrm{B}$ escribieron la notación musical sobre pentagramas trazados a mano alzada, mientras que $\mathrm{C}$ y D lo hicieron sobre otros delineados con rastrum. El formato básico de página del CMG empleado por los escribanos principales $(\mathrm{A}, \mathrm{B}$ y $\mathrm{C}$ ) consta de cinco pentagramas.

\section{INSCRIPCIONES SINGULARES}

A ninguno de los cuatro escribanos se deben dos anotaciones existentes en el CMG ajenas al contenido poético-musical. De un lado, en el margen inferior del f. [1r] puede leerse "Riera de la Visbal" escrito por una mano diferente a los cuatro copistas y con una tinta distinta a la usada en la propia página (ver fig. 5); la caligrafía podría corresponderse a la misma época o ser algo posterior. En Cataluña hay dos poblaciones llamadas "La Bisbal": La Bisbal d'Empordà y La Bisbal del Penedès. La primera localidad se encuentra a unos $30 \mathrm{~km}$ de Girona por carretera (18 km en línea recta), al noreste de Cataluña, y la segunda a unos $40 \mathrm{~km}$ de Tarragona, al sur de este territorio. La palabra "riera" puede interpretarse al menos de dos modos. Por una parte, "Riera" es un apellido catalán y, por tanto, la expresión "Riera de la Visbal" podría referirse a una persona portadora de tal patronímico que procediese de uno de los dos municipios citados. Por otra parte, "riera" significa en catalán "rambla" o "torrente". Existe una "riera de la Bisbal", exactamente así llamada, que pasa por La Bisbal del Penedés y desemboca en el mar Mediterráneo a unos $15 \mathrm{~km}$ hacia el sur. Pero también los habitantes de La Bisbal d'Empordá llaman "riera" al río Daró, que pasa por el municipio; de hecho, el portal principal de la ciudad, situado frente al cauce, al que llegaba el antiguo camino de Gerona se llama "portal de la Riera" y la calle que comunica este punto con la plaza mayor es el "carrer de la Riera" (Ajuntament de La Bisbal d'Empordà, 2018; Selfa Sastre, 2010, pp. 140-141). A uno de estos dos cauces podría, en principio, referirse la inscripción referida.

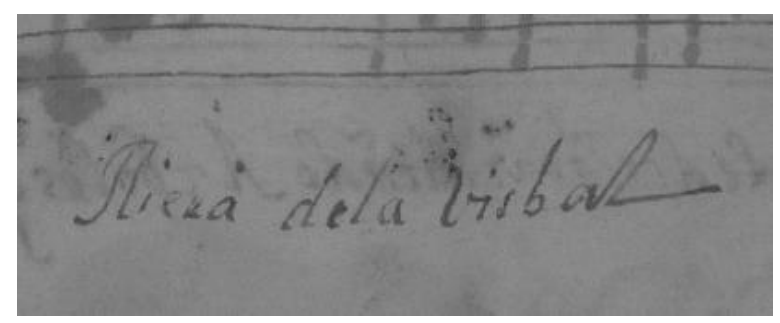

Fig. 5: Anotación "Riera de la Visbal". (E-Gah, ms. 34, f. [1r]).

Por otra parte, en el margen superior del f. [3r], se puede leer "Al molt Juan Gasco", escrito también por una mano diferente a los escribanos del manuscrito y de la anotación antes citada (ver fig. 6). La expresión "Al molt" es una fórmula catalana de encabezamiento 


\section{El CANCIONERo MUSiCAL DE GERONA:}

de escritos dirigidos a personajes poderosos. No obstante, en este caso la fórmula carece del tratamiento y del cargo del hipotético destinatario ${ }^{16}$. El nombre de pila de este personaje (“Juan”) podría ser castellano o catalán, si se asume una transcripción fonética, mientras que el apellido ("Gascó”) es inequívocamente catalán. Podría pensarse que la inscripción fuese una dedicatoria de la correspondiente pieza musical a un personaje de este nombre, cuya identidad se desconoce. Pero también este tipo de inscripciones en forma de encabezamientos se realizaba muy frecuentemente en la época con la única finalidad de hacer probaturas con la pluma antes de acometer un escrito en otro papel. Si se considera que el hipotético encabezamiento está incompleto, la deficiente caligrafía y la mano diferente a la de los escribanos del CMG, lo más probable es que esta anotación no fuese sino una simple prueba de pluma posterior a la copia del contenido del manuscrito.

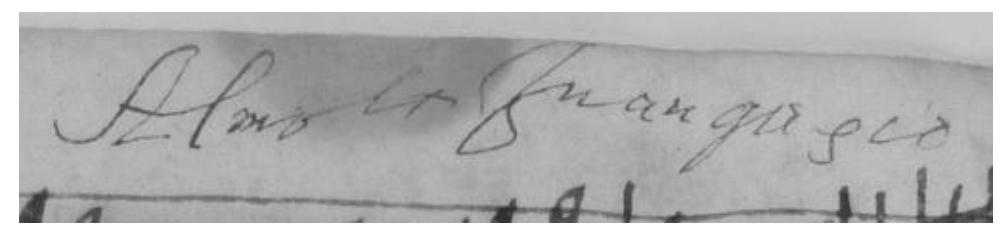

Fig. 6: Anotación "Al molt Juan Gascó”.

(E-Gah, ms. 34, f. [3r]).

\section{Contenido}

El CMG contiene veintitrés piezas musicales (ver detalles en apéndice 1). Cuatro están incompletas, bien por la falta del inicio ( $\left.\mathrm{n}^{\circ} 16\right)$ o final ( $\left.{ }^{\circ} 15\right)$ de la obra, o bien por la rotura de folio $\left(\mathrm{n}^{\circ} 22,23\right)$. Por otro lado, otra no presenta texto alguno bajo la notación musical $\left(n^{\circ} 1\right)$ y al menos otras dos carecen parcialmente de este $\left(n^{\circ} 3,4\right)^{17}$. En función de su estructura poético-musical, trece piezas pueden clasificarse como madrigales, ocho como villancicos y una como villanesca napolitana. La restante ( $\left.n^{\circ} 23\right)$ no puede clasificarse por estar muy incompleta. Solo seis de las piezas presentan concordancias musicales con otras fuentes (ver apéndices 1 y 2), por lo que el resto son unica.

Es posible aproximarse al número de voces del repertorio contenido en el CMG a través de dos evidencias. De un lado, las fuentes concordantes en que se conservan íntegramente las piezas $\mathrm{n}^{\circ} 15,19$ y 20 (ver apéndice 2), permiten conocer que estas obras son a 4 voces. De otro lado, en la única obra del manuscrito en que se explicita el número de partes (n²2) se indica que es a 5 voces (“a $5 \cdot$ vo.”). Así pues, se deduce que el CMG contiene al menos música compuesta a 4 y a 5 voces.

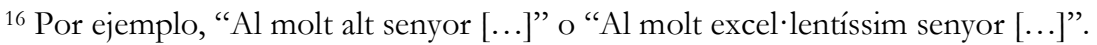

${ }^{17}$ La existencia de largas pausas en algunas piezas no permite descartar que estas presenten el texto incompleto en la parte musical contenida en el CMG.
} 


\section{FRANCESC VillanUEVA SERRANO}

Todos los poemas musicados son castellanos, a excepción de la villanesca napolitana (n²0), y de carácter profano, salvo uno de los villancicos ( $\left.{ }^{\circ} 14\right)$. Como suele ser habitual en este tipo de fuentes, la disposición de las sílabas del texto bajo las figuras musicales no es cuidadosa en el CMG, ni tampoco el propio contenido textual. En este sentido, se ha observado que se ha omitido alguna palabra, existente en las fuentes literarias, que es claramente necesaria para el correcto encaje del texto en la frase musical ${ }^{18}$. Mucho más evidente es la presencia de formas ortográficas particulares que delatan la lengua materna catalana de los copistas ${ }^{19}$.

Los autores de siete de los poemas han podido ser identificados con certeza y otro más con alguna duda (ver apéndices 1 y 2). Cinco de los de atribución segura pertenecen al ilustre binomio formado por Boscán $\left(\mathrm{n}^{\circ} 2,12\right)$ y Garcilaso $\left(\mathrm{n}^{\circ} 8,13,19\right)$, pioneros en la poesía de corte italiano en la península. No en vano, todos estos textos proceden del difundidísimo impreso citado Las obras de Boscán y algunas de Garcilaso de la Vega. Probablemente, estos poemas tan consagrados eran una óptima elección para el compositor de la segunda mitad del siglo XVI a la hora de abordar un género musical sofisticado ${ }^{20}-\mathrm{y}$, seguramente, por ello prestigioso- como el madrigal, al que estas cinco piezas pertenecen. Las obras con textos de los otros poetas identificados, los portugueses Pêro de Andrade Caminha ( ${ }^{* 1520 c ; ~ † 1591) ~ y ~ J o r g e ~ d e ~ M o n t e m a y o r ~[M o n t e m o r] ~(* 1520 c ; ~}$ †1561c), son dos villancicos $\left(\mathrm{n}^{\circ} 4,7\right)$ y, quizá, otro madrigal ( $\left.\mathrm{n}^{\circ} 14\right)$. Estos autores pertenecieron a una generación posterior a Boscán y Garcilaso, más cercana al manuscrito, pero nunca alcanzaron la misma fama.

Los copistas revelan los autores de la música en seis de las piezas del CMG, siendo todas ellas unica. A "Çorita" (Nicasi Sorita) se le atribuyen tres madrigales titulados $Y$ an muy poquito sabido ( $\left.\mathrm{n}^{\circ} 5\right)$, Spiritu gentil, rara figura $\left(\mathrm{n}^{\circ} 6\right)$ y Más que aré en tanta desventura ( $\left.\mathrm{n}^{\circ} 8\right)$ así como el villancico Zagal, alegre te veo $\left(\mathrm{n}^{\circ} \mathrm{7}\right)$. Se trata de las primeras obras en castellano de este autor de cuya existencia se tiene noticia. La trayectoria vital de Sorita presenta grandes lagunas. Es conocido que en 1570 era organista y maestro de canto en la iglesia de San Pedro del municipio valenciano de Sueca (Furió, 1980, pp. 13, 32). El desempeño de este puesto de carácter rural, que apunta a su etapa juvenil, y el uso de la lengua catalana por parte del músico (ver fig. 7$)^{21}$ podrían sugerir un origen o, al menos, la crianza en el reino valenciano $^{22}$. Desde la ciudad de Valencia se mudó a Tarragona en 1578, en cuya catedral ejerció el magisterio de capilla hasta 1587 (Stevenson, 1993, pp. 391-393). Mientras ocupaba este cargo, estampó en la imprenta barcelonesa de Hubert Gotard su Liber primus

\footnotetext{
18 Un ejemplo claro es la omisión de la palabra "señora" al final del primer verso de la pieza nº (ver apéndice 2).

19 Ejemplos del escribano A: "seguindo" en vez de "siguiendo" (n²); "duenyo" en vez de "dueño" (n4). Ejemplos del escribano B: "verdat" en vez de "verdad" (n8); "dirle” en vez de "decirle" (n9). Ejemplos del escribano C: "anochese" en vez de "anochece" (n¹7); "conocet" en vez de "conoced" (n¹7).

20 "En los madrigales, más que en otro género de composición, es tenido el composidor de explicar el sentido de la letra" (Cerone, 1613, p. 693; Ezquerro Esteban, 2007, vol. II, p. 925).

21 Transcribimos al catalán actual la "ç" en posición inicial como "s" (Sorita). La forma "Zorita" es una transcripción castellana cuyo uso no consta por parte del autor ni de su entorno.

22 Esta posibilidad diverge de la idea ampliamente extendida de que Sorita era aragonés, débilmente fundamentada en la "desinencia aragonesa" de su patronímico que percibió Felip Pedrell: "Aquest autor no es català: bé ho dóna a compendre la dessinencia aragonesa del cognom” (Pedrell, 1907, p. 2). Más tarde, Anglés sentenció con contundencia: "El mismo Nicasio Çorita (Zorita), natural de Aragón y maestro de capilla de la catedral de Tarragona, autor de un libro de motetes, era de origen aragonés” (Anglés, 1968, p. 95).
} 


\section{El CANCIONERO MUSICAL DE GERONA:}

de motetes $(1584)^{23}$. Parece que la fama de Sorita no llegó con fuerza más allá del entorno de las ciudades donde desarrollo su actividad. De hecho, no solo se preservan hoy en la Comunidad Valenciana y Cataluña casi todas las fuentes, tanto manuscritas como impresas, que contienen su legado musical sino que también se localizan los testimonios escritos de manuscritos desaparecidos con obras suyas ${ }^{24}$. Por el contrario, pese al conocimiento que del compositor aparentó tener el cantor de la capilla real española Pietro Cerone ${ }^{25}$, no parece que la música de Sorita hubiese alcanzado apreciablemente las tierras castellanas, pues no ha dejado huellas.

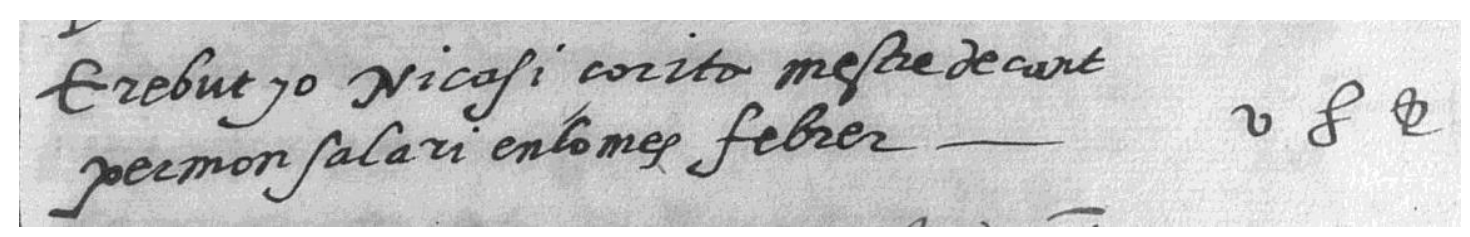

Fig. 7: Recibo autógrafo de Nicasi Sorita.

(E-TAc, Llibre de l'Obra, 76, N. 175, f. 441) 26.

Otro villancico titulado Que a mi caro me a costado ( $\mathrm{n}^{\circ} 11$ ) es atribuido en el CMG a "Pedro Ortega". Este músico tuvo una larga carrera como maestro de capilla, que inició en la recién creada catedral de Orihuela de 1562 hasta al menos 1564 (Rodríguez García, 2008, pp. 21-22). Con posterioridad, ejerció en la catedral de Sigüenza, de 1568 a 1579 (Jambou, 1983, p. 280). De aquí pasó brevemente por las Descalzas Reales en Madrid, de 1579 a 1580 (Mota Murillo, 1980, vol. I, p. 48), antes de recalar finalmente en la catedral de Murcia, donde ejerció de 1580 a 1610 (Prats Redondo, 2000, p. 893). Sus escasas obras litúrgicas conservadas se encuentran en Murcia y Baeza ${ }^{27}$; además, consta que en 1604 existía un libro de fabordones y magníficats de "Ortega" en Madrid $^{28}$. Respecto a la música en romance, el villancico del CMG sería la primera pieza atribuible con total certeza al autor. No obstante, en el CMM se conserva otro villancico profano atribuido a "Ortega"

\footnotetext{
${ }^{23}$ Felipe Pedrell fue el primero que trató sobre este impreso (Pedrell, 1899). Una relación pormenorizada de las piezas que contiene en Llorens Cisteró, 1987, pp. 240-241.

${ }^{24}$ En Barcelona, se conservan cuatro libretes del Liber primus (E-Bbc (3); E-Boc (1)); en Segorbe otros dos libretes de la misma obra (E-SEG) y en Bogotá (Colombia) solo uno (CO-B). En Barcelona, se conservan dos de las fuentes manuscritas (E-Bbc, ms. 589 y E-Boc, 6) y otras dos en Valencia (E-VAcp, LP 20 y 22). El detalle de obras concretas y signaturas en Llorens Cisteró, 2002, pp.240-241; Puentes-Blanco, 2018, pp. 98, 116, 126; apéndice: 37-38, 139, 196, 205. Consta la existencia de obras perdidas de Sorita en dos inventarios de 1632 y 1657 de la catedral de Valencia y en otro de 1625 del Real Colegio de Corpus Christi de la misma ciudad (Climent Barber \& Piedra Miralles, 1977, pp. 156, 160; Climent Barber, 1966, p. 219). Además, en la colegiata de Gandía había a finales del siglo XIX un ejemplar del Liber primus de motetes (Pedrell, 1899, p. 420).

${ }^{25} \mathrm{El}$ músico bergamasco afirma que "Ya muchos días ha que hize reverencia al señor Nicasio Zorita, y siempre alabé y soy para alabar sus eccelentes composiciones" antes de relatar una anécdota sobre un maestro de capilla que intentó atribuirse una obra de Sorita (Cerone, 1613, p. 109; Ezquerro Esteban, 2007, p. 341).

${ }^{26}$ Derechos reservados $(\mathrm{C}$ Arxiu Històric Arxidiocesà de Tarragona.

27 E-MUc, A-9, ff. 31-38 (7 piezas); E-BAE, 4, ff. 73v-75r (1 pieza). Ros-Fábregas y Marín-López, $2020 \mathrm{~b}$. Marín López, 2007, pp. 326, 343.

28 Aparece este libro en un inventario de las Descalzas Reales (Olmos, 2003, p. 479).
} 


\section{FRANCESC VilLANUEVA SERRANO}

cuya identificación con Pedro Ortega es ahora más verosímil tras constatarse su desempeño compositivo en este campo ${ }^{29}$.

El último autor con una atribución explicita en el CMG es Francisco Guerrero (*1528; †1599), cuya copiosa obra fue, sin duda, la más difundida en la península ibérica durante la segunda mitad del siglo XVI y primeras décadas del siglo XVII. Aunque en su juventud fue brevemente maestro de capilla en la catedral de Jaén (1546-1549), Francisco Guerrero pasó casi toda su vida en la catedral de Sevilla sucesivamente como cantor, maestro de los niños cantorcicos y, finalmente, como maestro de capilla desde $1574^{30}$. Son bastantes los villancicos y madrigales conservados de este autor, la mayoría de los cuales, con textos de carácter religioso, están recogidos en su impreso Canciones y villanescas espirituales (Guerrero, 1589) ${ }^{31}$ que contiene 61 de estas obras. Su música profana ha llegado a nuestros tiempos en menor proporción, en gran parte en forma de contrafacta, y están incluidas en el CMM y CMLG. El villancico religioso Si para remedio mío (n¹4) del CMG, que es atribuido a "F. Guerrero", es una nueva obra a añadir al catálogo del célebre compositor sevillano.

Además de las atribuciones explícitas, es posible la identificación de los autores de la música de cuatro más de las piezas castellanas gracias a sus concordancias con otras fuentes de época (ver apéndice 2). Tres de ellas - Amor es voluntad dulce y sabrosa ( $\left.{ }^{\circ} 12\right)$, Tu dulce babla en cuya oreja suena ( $\left.\mathrm{n}^{\circ} 13\right)$, O más dura que mármol ( $\left.\mathrm{n}^{\circ} 19\right)$ - son madrigales de Pedro Guerrero (*1520c), hermano mayor y maestro de Francisco Guerrero, que se recogen en forma de arreglos vihuelísticos en Orphenica Lyra de Miguel de Fuenllana (1554) ${ }^{32}$. La selección de estas piezas para formar parte de esta última publicación sugiere su alta popularidad en la península, en la cual pudo también colaborar su hipotética inclusión en el impreso perdido Sonetos y madrigales difíciles de Pedro Guerrero (Iglesias, 1998, pp. 461-503) ${ }^{33}$.

No obstante, todas las piezas anteriores fueron seguramente superadas en el escalafón hispánico de la fama por el madrigal Sobre una peña do la mar batía (n¹5) de [Juan] Navarro (*1530c; †1580). No en vano, es la pieza castellana con mayor presencia en las fuentes de la época, dado que antes de hallarse en el CMG ya se conocía su presencia en CMM, CMLG y V17. Tras ejercer en su juventud como cantor en tierras andaluzas, Navarro fue maestro de capilla en numerosos templos castellanos: de 1562 a 1564 en la colegiata de Valladolid; de 1564 a 1566 en la catedral de Ávila; de 1566 a 1544 en la catedral de Salamanca; de 1574 a 1578 en la catedral de Ciudad Rodrigo; y de 1578 a 1580 en la catedral de Palencia (Gómez Pintor, 2000). La mayor parte de su producción conservada forma parte del impreso Psalmi, bymni ac Magnificat totius anni (1590), muchas de cuyas piezas circularon en copias manuscritas. La fama del compositor y la difusión de su obra en la

\footnotetext{
29 Pues que me tienes, Miguel (CMM, ff. 60v-61r). Miguel Querol propuso tres candidatos diferentes para su autor de quienes no hay indicios de que fuesen compositores (Querol Gavaldá, 1950, vol. I, pp. 29, 97-100).

${ }^{30}$ Ver, por ejemplo, Barrionuevo, 2000.

31 Edición en Querol Gavaldá \& García Julbe, 1955 y 1957.

${ }^{32}$ Edición completa en Jacobs, 1978. Facsímil en Arriaga, 2003.

${ }_{33}$ Un catálogo de obras conocidas de Pedro Guerrero y de fuentes que las transmiten en Iglesias, 1998, pp. 470-474.
} 
EL CANCIONERO MUSICAL DE GERONA:

MADRIGALES Y VILLANCICOS EN UNA NUEVA FUENTE HISPÁNICA DEL SIGLO XVI

península ibérica fue notable ya que las fuentes que la transmiten son numerosas y están muy diseminadas geográficamente ${ }^{34}$.

La única pieza del CMG con texto no castellano, la villanesca Se pur te guardo (n²0) que las fuentes atribuyen a Adrian Willaert o Roger Pathie, fue publicada como obra vocal junto a otras de Baldassara Donato en Il primo libro di canzon Villanesche alla Napolitana a quatro Voci (Venecia: Antonio Gardane, 1550). Tuvo una extraordinaria difusión en Europa a través de sus numerosísimas versiones instrumentales para tecla, laúd, vihuela o guitarra, un par de las cuales se adelantaron, incluso, a la impresión de la versión vocal. De hecho, en 1547 ya era conocida en España, cuando Enríquez de Valderrábano incluyó un arreglo para vihuela en su impreso Silva de Sirenas (ver apéndice 2).

Del villancico anónimo Quien a dos amores ama ( $\left.\mathrm{n}^{\circ} 10\right)$ se conservan dos partes en el CMV, escritas en clave de G2, diferentes a la contenida en el CMG en clave de C1. La música de las tres partes encaja perfectamente y, respecto al texto, solo difieren en las mudanzas. Si se reconstruye el contrapunto imitativo al inicio de la pieza en una cuarta voz, se observa que el sujeto finaliza precisamente en la primera cláusula (cc. 13-14), lo que apunta a que la pieza es a cuatro voces (ver ej. $1^{35}$ ).
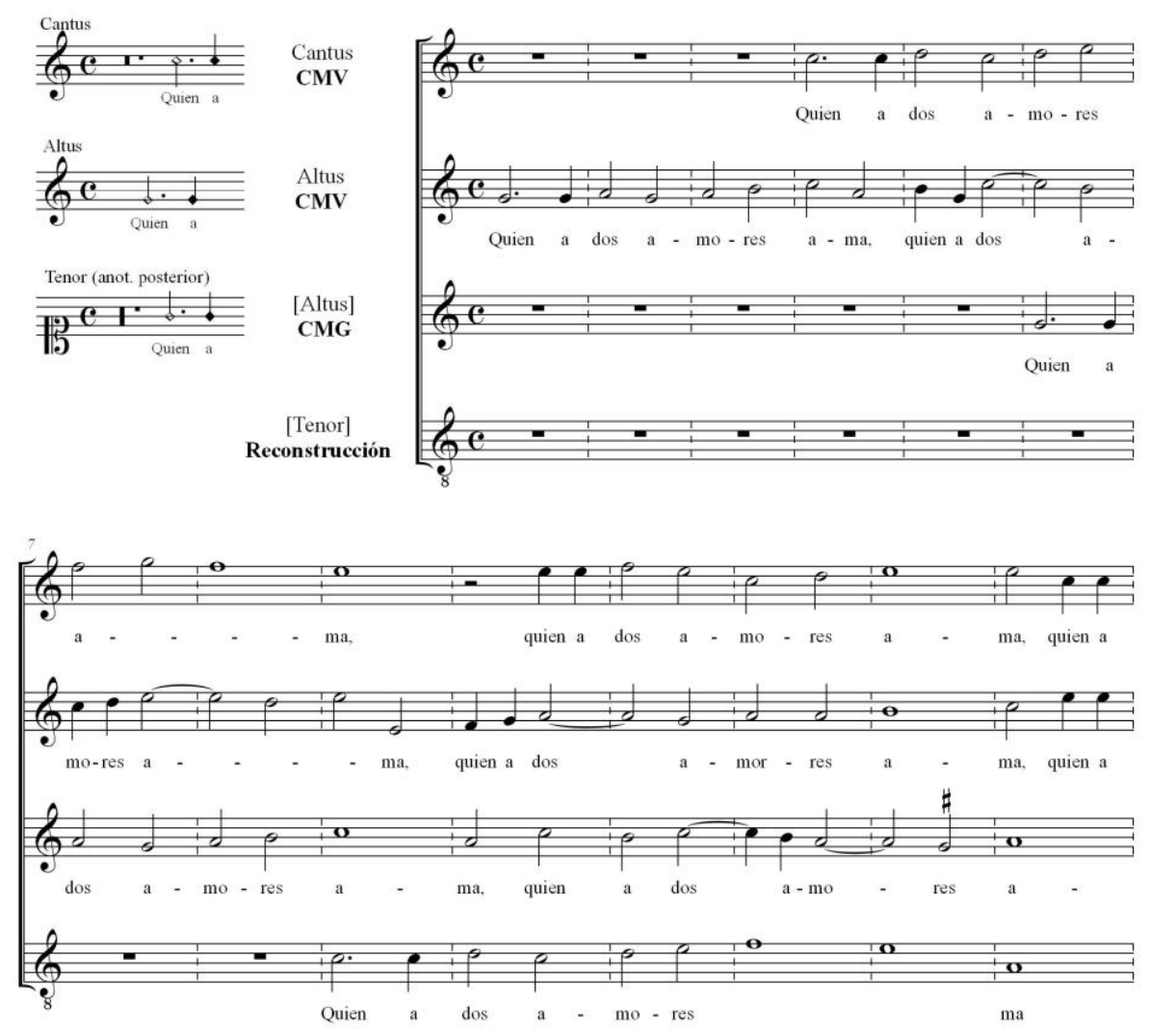

Ej. 1: Inicio de Quien a dos amores ama.

\footnotetext{
${ }^{34} \mathrm{La}$ base de datos Books of Hispanic Polyphony cita la existencia de 39 fuentes manuscritas conteniendo obras suyas en la península ibérica, localizadas en 28 archivos diferentes. Del impreso consta la conservación de 11 copias en otros tantos archivos peninsulares (Ros-Fábregas y Marín-López, 2020a).

35 Véase una reconstrucción completa de la pieza en Villanueva Serrano, 2021.
} 


\section{FraNCESC VilLANUEVA SERRANO}

\section{PROCESO DE CONFECCIÓN}

Los dos fascículos que componen el CMG no se generaron unitaria y homogéneamente, sino que fueron escritos por diversas personas y en distintos momentos, aunque no muy alejados en el tiempo. De ello son testimonio algunas particularidades que pueden ser rastreadas a través de detalles codicológicos y de contenido.

El núcleo más antiguo del fascículo 1 (cuaternión) está formado por sus dos bifolios interiores (ff. [3]-[6]). Precisamente aquí comienza la labor del copista B con las cuatro piezas de Nicasi Sorita ( $\left.{ }^{\circ} 5,6,7,8\right)$. Durante este trabajo anotó "Tertio" encabezando la tercera de ellas (f. [4v]) y "Finis" cerrando la cuarta y última. Estas expresiones delimitadoras, junto al singular protagonismo de Sorita y el hecho de que la participación de B en el CMG se ciña exclusivamente a los tres primeros folios de este binión sugieren la independencia original de este respecto a los otros dos bifolios del fascículo 1. Inmediatamente o poco después de reproducir las obras de Sorita, la misma mano continuó copiando la siguiente pieza anónima $\left(\mathrm{n}^{\circ} 9\right)$, que fue la última que escribió. Este binión debió de ser usado antes de la compilación del CMG conteniendo únicamente estas cinco piezas. La posibilidad de que hubiese formado parte de otro manuscrito no es descartable pero se estima menos probable ya que no se aprecian otros puntos de cosido en los bifolios diferentes a los del actual CMG.

En un momento posterior, un nuevo copista (A) añadió al menos dos bifolios adicionales en blanco externamente al binión antes referido, en cuya unión tiene su origen el cuaternión actual (fascículo 1). Comenzó entonces a copiar las piezas que encabezan el actual manuscrito ( $\left.\mathrm{n}^{\circ} 1,2,3,4\right)$ en los primeros dos nuevos folios (ff. [1]-[2]). Comoquiera que al llegar al f. [3] se encontró con los folios escritos por B (ff. [3]-[5]), saltó adelante y continuó copiando dos nuevas piezas (n¹0-11) en el f. [6] que, aunque formaba parte del binión primigenio, estaba en blanco. Parece que fue al finalizar esta pieza cuando el copista A efectuó las cuatro inscripciones de "Tenor" (ver figs. 8 y 9) que contiene el CMG, tanto sobre piezas copiadas por él $\left(\mathrm{n}^{\circ} 3,10,11\right)$ como sobre una copiada anteriormente por B $\left(\mathrm{n}^{\circ} 9\right)$. De hecho, no solo todas estas anotaciones están sobre la música hasta entonces escrita (por A y B) sino que el tono de la tinta empleada se corresponde con el de las últimas piezas copiadas ( $\left.\mathrm{n}^{\circ} 10-11\right)$.

La prosecución del trabajo de A en los folios posteriores añadidos por él (ff.[7]-[8]) con la copia de las piezas no 12-15 no parece que fuese inmediata puesto que el estilo de ornamentación de las capitales es diferente respecto al empleado en los folios copiados anteriormente. La abrupta interrupción de la pieza $\mathrm{n}^{\circ} 15$ al final del f. [8v] señala con claridad que el copista A había dispuesto y escrito, al menos, un bifolio más en el mismo fascículo o bien otro fascículo contiguo para finalizar esta obra que, en cualquier caso, fueron separarados con posterioridad y se extraviaron. De un modo u otro, los cuatro o más bifolios agrupados en el fascículo creado por A también pudieron usarse, sueltos o en el interior de otro manuscrito mayor, previamente a la compilación del CMG. La última opción tampoco parece muy probable por la misma razón de la inexistencia de orificios de cosido adicionales. 


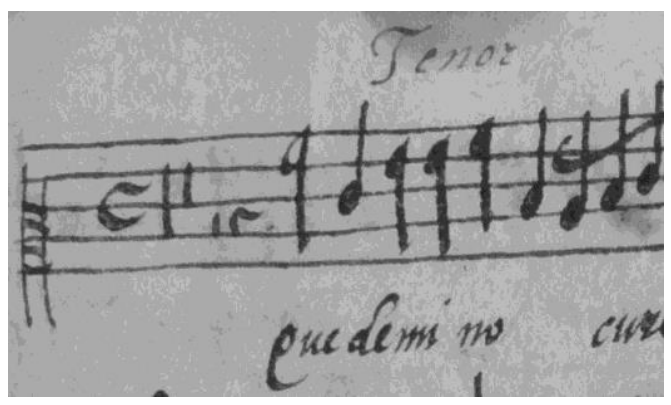

Fig. 8: Inscripción “Tenor” en n ${ }^{\circ}$. Copista A sobre notación de B.

(E-Gah, ms. 34, f. [5v]).

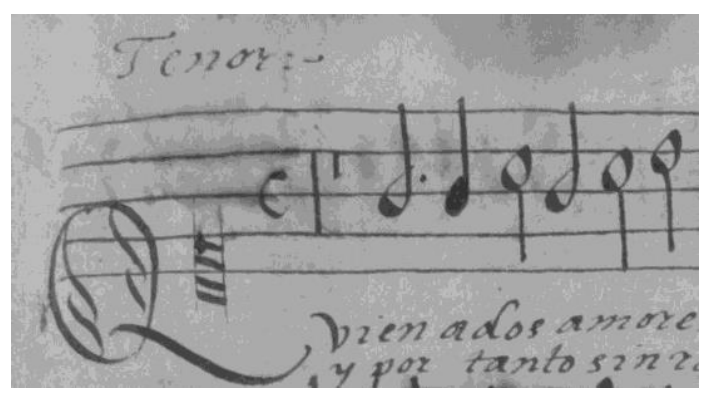

Fig. 9: Inscripción “Tenor" en n¹0. Copista A sobre notación de A.

(E-Gah, ms. 34, f. [6r]).

De otro lado, el fascículo 2 del CMG (ff. [9]-[12]) fue copiado íntegramente por C a excepción de la pieza añadida posteriormente por $\mathrm{D}$ en la última página (n²3); y ambos copistas son también exclusivos de este binión. Su contenido comienza con una pieza que carece de su inicio ( $\left.\mathrm{n}^{\circ} 16\right)$, lo cual delata que de este binión fue separado algún bifolio que lo abrazaba o fascículo precedente, donde comenzaba la obra. Es más, la paginación particular de este fascículo, que comienza con el " 5 " desvela que fueron dos los folios que antecedían al binión actual. Ello podría indicar que existía un bifolio independiente delante o dos bifolios exteriormente al binión actual, en cuyo caso conformarían originalmente un cuaternión. Todo este conjunto de constataciones sugiere, asimismo, el diferente origen del fascículo 2 y su uso antes de compilarse el CMG. Atendiendo a la ausencia de orificios adicionales de cosido en el papel de sus bifolios, y teniendo en cuenta la paginación particular existente, se considera más probable que se emplease originalmente como un cuaternión suelto que como binión antecedido por un singulión, como parte de otro manuscrito.

Finalmente, los dos fascículos (1 y 2), originariamente formados por más bifolios o acompañados de otros fascículos, fueron compilados y encuadernados para crear el actual CMG.

\section{LAS CLAVES Y EL USO DEL CMG}

En el CMG se pueden encontrar piezas escritas en las claves de C1, C2, C3 y C4, que potencialmente pueden corresponder a todo el abanico de registros vocales: de la C1 de tiple a la $\mathrm{C} 4$ de tenor o bajo. Atendiendo a los dispares ámbitos vocales de las partes contenidas en el CMG (ver tabla 1), cuyos extremos son el Do3 y el Mi5, el librete no podría ser usado por un único cantor en las alturas escritas. 


\begin{tabular}{|c|c|c|c|c|c|c|c|c|c|c|c|c|c|c|c|}
\hline $\mathrm{n}^{\mathbf{o}}$ & Fasc & Clave & Do3 & Re3 & Mi3 & Fa3 Sol3 & La3 & Si3 1 Do4 & \begin{tabular}{|l|l|} 
Re4 & $\mathbf{M i} 4$ \\
\end{tabular} & Fa4 & Sol4 I & La4 & \begin{tabular}{|l|l|} 
Si4 & Do5 \\
\end{tabular} & $\operatorname{Re} 5 \mid \Lambda$ & Mi5 \\
\hline 1 & \multirow{15}{*}{1} & $\mathrm{C} 2$ & & & & & & & & & & & & & \\
\hline 2 & & $\mathrm{C} 4$ & & & & & & & & & & & & & \\
\hline 3 & & C1 & "Tet & hor" & & & & & & & & & & & \\
\hline 4 & & C1 & & & & & & & & & & & & & \\
\hline 5 & & C3 & & & & & & & & & & & & & \\
\hline 6 & & $\mathrm{C} 2$ & & & & & & & & & & & & & \\
\hline 7 & & C3 & & & & & & & & & & & & & \\
\hline 8 & & $\mathrm{C} 4$ & & & & & & & & & & & & & \\
\hline 9 & & $\mathrm{C} 2$ & "Te & nor" & & & & & & & & & & & \\
\hline 10 & & C1 & "Te & nor" & & & & & & & & & & & \\
\hline 11 & & $\mathrm{C} 2$ & "Te & nor" & & & & & & & & & & & \\
\hline 12 & & $\mathrm{C} 4$ & & & & & & & & & & & & & \\
\hline 13 & & $\mathrm{C} 4$ & & & & & & & & & & & & & \\
\hline 14 & & $\mathrm{C} 3$ & & & & & & & & & & & & & \\
\hline 15 & & $\mathrm{C} 2$ & & & & & & & & & & & & & \\
\hline 16 & \multirow{8}{*}{-} & $\mathrm{C} 3$ & & & & & & & & & & & & & \\
\hline 17 & & $\mathrm{C} 4$ & & & & & & & & & & & & & \\
\hline 18 & & $\mathrm{C} 4$ & & & & & & & & & & & & & \\
\hline 19 & & $\mathrm{C} 4$ & & & & & & & & & & & & & \\
\hline 20 & & $\mathrm{C} 4$ & & & & & & & & & & & & & \\
\hline 21 & & $\mathrm{C} 4$ & & & & & & & & & & & & & \\
\hline 22 & & $\mathrm{C} 4$ & & & & & & & & & & & & & \\
\hline 23 & & $?$ & & & & & & & & & & & & & \\
\hline
\end{tabular}

Tabla 1: Ámbitos de las partes vocales del CMG.

(Elaboración propia).

Cabría preguntarse primeramente si, dada la gran variedad de claves empleadas y los diferentes ámbitos de las piezas, el CMG podría ser un librete de Quintus (Quinta pars, Quinto), cuyas partes frecuentemente estaban escritas para diversos registros vocales. Esta posibilidad se ha de descartar, dado que las tres únicas piezas del CMG conservadas completas en otras fuentes en versión vocal son a cuatro voces y, en los tres casos, las partes se corresponden con voces básicas (alto en el n¹5 y tenor en los n¹9,20).

En la búsqueda de otra posible explicación a esta característica del CMG es preciso formular tres consideraciones previas. Por un lado, si se observa la distribución de claves por fascículos (ver tabla 1), se aprecia que en el 1 son empleadas todas ellas (C1, C2, C3 y C4) en similar proporción, mientras que en el 2 hay seis piezas en $\mathrm{C} 4$ y una en C3. Este último fascículo es, por tanto, mucho más homogéneo desde este punto de vista y se ajusta perfectamente a un registro de tenor, que ordinariamente se escribe en claves de C4 o C3. Por otra parte, en el CMG solo se indican explícitamente las partes vocales en cuatro de sus piezas $\left(n^{\circ} 3,9,10,11\right)$, todas las cuales están encabezadas por la inscripción "Tenor" efectuada por el copista A; pertenecen al fascículo $1 \mathrm{y}$, sorprendentemente, están escritas en claves de $\mathrm{C} 1$ y C2. En tercer lugar, las partes vocales de las tres piezas del CMG concordantes con otras fuentes vocales completas $\left(n^{\circ} 15,19,20\right)$ se corresponden con las 
El CANCIONERo MUSiCAL DE GERONA:

MADRIGALES Y VILLANCICOS EN UNA NUEVA FUENTE HISPÁNICA DEL SIGLO XVI

terceras voces del entramado polifónico, posición que en el cuarteto ordinario corresponde al tenor. De acuerdo con los indicios expuestos, en este punto se tomará como hipótesis de trabajo que el CMG es un librete de tenor, y se tratará de dar una explicación a la existencia de piezas escritas con unos ámbitos mucho más agudos de los que son propios de este registro.

En las fuentes coetáneas de este tipo de repertorio no es extraño encontrar partes escritas en claves y con ámbitos que no se corresponden con los registros vocales señalados en el propio manuscrito ${ }^{36}$. Sin embargo, las claves empleadas en los casos divergentes suelen ser las más cercanas a las ordinarias, lo cual permite que los ámbitos no permanezcan muy alejados de los habituales ${ }^{37}$. Pero este no es precisamente el caso de las tres piezas del fascículo 1 escritas en claves en C1, que alcanzan el Re5 o el Mi5 inalcanzables para el tenor. Únicamente un transporte de un intervalo descendente muy amplio, entre una cuarta justa y una octava, podría desplazar el ámbito de las piezas en C1 y C2 al habitual del tenor del siglo XVI. La práctica del transporte en diversos intervalos era habitual en la época. Fray Juan Bermudo detalla los transportes posibles (modos accidentales) para cada uno de los ocho modos básicos cuando acompañaba un instrumento de tecla. Por ejemplo, para el primer modo (Re), define cinco posibilidades de transposición - por Do ( $2^{\mathrm{a}} \mathrm{M}$ descendente), Mi ( $2^{\mathrm{a}} \mathrm{M}$ ascendente), Sol (4 $4^{\mathrm{a}} \mathrm{J}$ ascendente), La ( $5^{\mathrm{a}} \mathrm{J}$ ascendente) y Si ( $6^{\mathrm{a}} \mathrm{M}$ ascendente $)$ - y sus octavas, todas las cuales no requieren más alteraciones que aquellas que entonces tenían las teclas negras, es decir, Fa\#, Do\#, So\#, Sib y Mib (Bermudo, 1555, ff. LXXIIIv-LXXVIr). Incluso, el franciscano describe cómo se las ingeniaban en una capilla para conseguir el Lab en el órgano a través de la manipulación de sus mecanismos con la finalidad de poder transportar por $\mathrm{Fa}$ ( $3^{\mathrm{a}} \mathrm{m}$ ascendente), adaptándose así a las posibilidades vocales de sus cantores (Bermudo, 1555, f. LXXXXv).

Una adecuada transposición también posibilitaría que muchas de las obras en principio escritas para un cuarteto con tres voces agudas (dos escritas en G2 y una en C1) fuesen interpretables por un cuarteto ordinario de tiple, alto, tenor y bajo. Como ejemplo, la célebre Sobre una peña do la mar batía (n¹5), única pieza del fascículo 1 que se conserva completa en versión vocal en otra fuente, está escrita en el CMM con las claves y ámbitos siguientes: G1 (Sol4-Sol5); C1 (La3-Re5); C2 (La3-Sib4); C4 (Do3-Fa4). La parte conservada en el CMG es la tercera y está escrita en la misma clave de C2. En este caso, un transporte de una cuarta o una quinta haría posible la interpretación a un cuarteto ordinario. Mayor intervalo se requeriría para interpretar por el mismo cuarteto muchas de las piezas escritas con las claves G2-G2-C1-C3 de este repertorio. Por ejemplo, las claves y ámbitos de las tres partes conocidas de Quien a dos amores ama (n¹0) son G2 (Sol4-Sol5),

\footnotetext{
${ }^{36}$ Las claves ordinariamente usadas son C1 y G1 para tiple; C3 y C2 para alto; C4 y C3 para tenor y F4, F3 y C4 para bajo. En este repertorio, es habitual que las claves empleadas no se ajusten a los sistemas estándar de claves bajas o altas.

37 Además de los ejemplos del CMM y del CMV anteriormente expuestos, en la Recopilación de sonetos y villancicos de Juan Vázquez puede encontrarse: alto en C1 ( $\mathrm{n}^{\circ} 1$ de la edición Anglés, 1946); alto en C1 y tenor en C2 ( $\left.\mathrm{n}^{\circ} 3\right)$; alto en C1 ( $\left.\mathrm{n}^{\circ} 4\right)$; alto en C1 ( $\left.\mathrm{n}^{\circ} 6\right)$; tenor en F3 ( $\left.\mathrm{n}^{\circ} 7\right)$; alto en C4 y tenor en F3 ( $\left.\mathrm{n}^{\circ} 8\right)$; tenor en F3 $\left(\mathrm{n}^{\circ} 10\right)$; alto en C4 y tenor en F4 ( $\left.\mathrm{n}^{\circ} 13\right)$; alto en C1 ( $\left.\mathrm{n}^{\circ} 15\right)$; tenor en F3 ( $\left.\mathrm{n}^{\circ} 17\right)$; tenor en F3 $\left(\mathrm{n}^{\circ} 18\right)$.
} 


\section{FRANCESC VillanUEVA SERRANO}

G2 (Mi4-Sol5), C1 (Do4-Mi5), las cuales requerirían una transposición de alrededor de una sexta para que fuese practicable por tiple, alto y tenor.

En consecuencia, todo apunta a que el CMG es un librete de tenor que contiene, tanto partes escritas originalmente para este registro (parte del fascículo 1 y todo el fascículo 2), como otras que son las terceras voces de piezas con esquemas vocales más agudos (resto del fascículo 1), las cuales podrían ser interpretables por un cantor tenor a través de la transposición. Esta práctica podía permitir a un cuarteto de voces ordinario el acceso a gran parte de este último tipo de repertorio circulante por la península.

\section{ORIGEN}

El CMG transmite una pieza de amplia difusión en Europa y otras de músicos con proyección peninsular como Francisco Guerrero, Juan Navarro, Pedro Guerrero y, aunque en un escalón inferior, Pedro Ortega. Pero, ciertamente, en este manuscrito tiene un protagonismo inusitado otro autor de alcance local o, acaso, regional como Nicasi Sorita. Generalmente, el origen de un libro de música viene señalado por estos autores de impacto localizado. De acuerdo con esta primera aproximación, la zona más probable para la generación del CMG abarcaría los territorios del antiguo reino de Valencia y de Cataluña, donde este músico tuvo una recepción apreciable, en cuyo caso también se justificaría la lengua materna catalana de los copistas. No obstante, la inscripción "Riera de la Visbal" permite acercarse más, puesto que apunta a las localidades catalanas de La Bisbal d'Empordà y La Bisbal del Penedès, independientemente de que "Riera" pueda ser un nombre común (rambla) o, incluso, un patronímico. Ciertamente, en el contexto de una pequeña localidad con escasez de cantores y, por tanto, con necesidad de adaptar piezas a las voces disponibles, encaja un sencillo manuscrito como este ${ }^{38}$. Ambos municipios reúnen circunstancias favorables a sus candidaturas. La Bisbal del Penedès tiene a su favor la existencia de una "Riera de la Bisbal", así oficialmente llamada, y, además, su situación en el área de influencia próxima de Tarragona, única ciudad catalana donde Nicasi Sorita desarrolló su magisterio de capilla. En cambio, su candidatura no puede presentar una explicación al hecho de que el manuscrito se conserve en un archivo administrativo del ámbito provincial de Gerona sin formar parte de esa demarcación y distando, además, unos $160 \mathrm{~km}$ de su capital. En contraposición, La Bisbal d'Empordà, que también posee una riera así llamada por sus habitantes, conserva sus protocolos notariales de la época precisamente en el Arxiu Històric de Girona. Entre estos fondos bien pudo haber llegado traspapelado este manuscrito ${ }^{39}$.

\footnotetext{
${ }^{38}$ Semejante ambiente musical en una zona rural es retratado por Honorat Ciuró para la comarca catalana del Rosellón a mediados del siglo XVII (Mazuela-Anguita, 2016).

${ }^{39} \mathrm{El}$ Arxiu Històric de Girona no dispone de información específica sobre la procedencia del manuscrito. No obstante, desde el mismo archivo, D. Santiago Soler i Simón sugiere aquella posibilidad. Agradezco la atención recibida en esta institución.
} 
El CANCIONERo MUSiCAL DE GERONA:

MADRIGALES Y VILLANCICOS EN UNA NUEVA FUENTE HISPÁNICA DEL SIGLO XVI

\section{DATACIÓN}

Por razones de proximidad geográfica y de pertenencia al mismo estado político catalán, resulta más verosímil que fuese desde Tarragona, y no desde Valencia, desde donde se difundiesen las obras de Sorita recogidas en el CMG. Bajo este supuesto razonable, hay que asumir que estas fueron copiadas después de 1578, año en que el músico llegó a la ciudad catalana. De acuerdo con el proceso de formación del fascículo 1 anteriormente expuesto, el resto de piezas de ese fascículo se copiaron con posterioridad. Esta aproximación cronológica también se alinea con las horquillas, solo orientativas, que sugieren las filigranas del papel.

El fascículo 2 contiene dos piezas que debieron de circular desde bastante tiempo atrás. De hecho, la villanesca napolitana Se pur te guardo ya había sido impresa en 1550 y el madrigal de Pedro Guerrero O más dura que mármol siguió el mismo camino en 1554 en la adaptación vihuelística de Fuenllana y, quizá, también en versión vocal, como ya se ha apuntado. Es posible, por tanto, que este fascículo fuese escrito antes de 1578, lo que podría recibir el respaldo de la presencia de la filigrana del peregrino con letras, aunque no puede descartarse que ocurriese algo después.

Por tanto, bajo las premisas anteriores, la compilación final del CMG fue necesariamente posterior a 1578. Probablemente, tuvo lugar unos años más tarde: los necesarios para que se compusiesen las obras, si es que no lo estaban cuando llegó Sorita a Tarragona; para que su música se difundiese por Cataluña; y para que el binión original del fascículo 1 llegase a tener un uso independiente.

No obstante, no parece razonable asumir el transcurso de muchos años desde 1578 para estimar el momento de la compilación, atendiendo a que toda la poesía musicada en el CMG es plenamente renacentista y podría resultar desfasada no mucho tiempo después de la aparición, hacia 1580, de los nuevos géneros asociados al Romancero en el entorno de la $\operatorname{corte}^{40}$. De hecho, el Cancionero de Olot, datable en la década de 1620-1630, contiene ya exclusivamente repertorio de los nuevos géneros poético-musicales, lo cual sugiere que estos estaban consolidados en el interior de Cataluña desde tiempo atrás (Torrente, 2016, p. $194)^{41}$. Considerando todo lo anterior, se estima que la compilación del CMG pudo producirse ca. 1590.

\section{CoNCLUSIÓN}

El estudio sobre el CMG apunta a que se trata de un librete de tenor compilado en torno a 1590 a partir de fascículos que habían tenido un uso anterior. Las limitaciones de medios musicales propias de un entorno rural como La Bisbal d'Empordà, donde probablemente tuvo su origen, encajan con la necesidad de adaptación práctica de los registros vocales originales de una parte de las piezas a través de la transposición. Pese a su carácter incompleto, el principal valor de este "nuevo" manuscrito reside en el repertorio

\footnotetext{
40 Análoga observación ya fue formulada por Margit Frenk para el caso del CMV (Frenk, 1992, p. 197).

${ }^{41}$ Edición en Civil i Castellví, 1982.
} 


\section{FranCESC VillanUeVA SERRANo}

que casi exclusivamente parte transmite, villancicos y madrigales profanos en castellano de la segunda mitad del siglo XVI, tan practicados en la península ibérica de la época como poco conservados.

\section{BIBLIOGRAFÍA}

Ajuntament de La Bisbal d'Empordà (2018). Els trencaments del Riu Daró a La Bisbal d'Empordà. Recuperado de http://www.labisbal.cat/ca/els-trencaments-del-riu-daroa-la-bisbal-d-emporda.html.

Alberch Vila, P. (1560). Odarum spiritualium musico, Liber secundus. Barcelona: Jaume Cortey.

Alberch Vila, P. (1561). Odarum (quas vulgo madrigales appellamus) diversis linguis decantatum barmonica, nova \& excellenti modulatione compositarum, Liber primus. Barcelona: Jaume Cortey.

Alín, J. M. \& Barrio Alonso, M. B. (1997). Cancionero teatral de Lope de Vega. Londres: Tamesis.

Ammerbach, E. N. (1571). Orgel oder Instrument Tabulatur. Leipzig: Jacob Berwalds Erben.

Ammerbach, E. N. (1583). Orgel oder Instrument Tabulatur, in sich begreiffende eine notwendige unnd kurtze anlaitung. Nuremberg: Katharina Gerlach.

Anastácio, V. (1998). Visões de Glória (uma introdução à poesia de Pêro de Andrade Caminha. [Lisboa]: Fundação Calouste Gulbenkian, Junta Nacional de Investigação Científica e Tecnológica.

Anglés, H. (Ed.) (1946). Juan Vásquez. Recopilación de Sonetos y Villancicos a quatro y a cinco (Sevilla, 1560). Barcelona: CSIC, Instituto Español de Musicología.

Anglés, H. (1948). El Archivo Musical de la Catedral de Valladolid. Anuario Musical, 3, pp. 59-108.

Anglés, H. (1968). Supervivencia de la música de Cabezón en los organistas españoles del siglo XVII. Anuario Musical, 21, pp. 87-104.

Arañés, J. (1624). Libro segundo de tonos y villancicos a una dos tres y quatro voces. Con la zifra de la Guitarra Espannola a la usanza Romana. Roma: Giovanni Battista Robletti.

Arriaga, G. (Ed.) (2003). Libros de música para vihuela (1536-1576). Madrid: Música prima. 


\section{El CANCIONERO MUSICAL DE GERONA:}

MADRIGALES Y VILLANCICOS EN UNA NUEVA FUENTE HISPÁNICA DEL SIGLO XVI

Arriaga, G. \& Frenk Alatorre, M. (Eds.) (2017). Cancionero musical y poético llamado Tonos Castellanos. Madrid: Sociedad Española de la Guitarra.

Baena Fernández, S., García Morales, S. \& Najar Torres, E. M. (2009). Estudio de la marca de agua en el fondo documental de Beneficencia del Archivo de la Diputación de Córdoba. Arcontes. Cuaderno del Archivo de la Diputación de Córdoba, 2, pp. 35-53.

Bal y Gay, J. (Ed.) (1944). Cancionero de Uppsala. Introducción notas y comentarios de Rafael Mitjana. Ciudad de México: El Colegio de México.

Balvas Barona, A. (1627). El poeta castellano Antonio Balvas Barona, natural de la ciudad de Segovia, a don Mateo Ibánez de Segovia, del hábito de Calatrava, tesorero general de Su Magestad. Valladolid: Juan de Rueda.

Barrionuevo, H. (2000). Francisco Guerrero (1528-1599). Vida y obra. La música en la catedral de Sevilla a finales del siglo XVI. Incluye el Viaje a Jerusalén de Guerrero. Sevilla: Cabildo Metropolitano de la catedral de Sevilla.

Basanta Campos, J. L. (1996). Marcas de agua en documentos de los archivos de Galicia hasta 1600, 8 vols. La Coruña: Fundación Pedro Barrié de la Maza.

Bermudo, J. (1555). Declaración de instrumentos musicales. Osuna: Juan de León.

Bornstein, A. (Ed.) (1998). Villancicos de diversos autores a doz vozes y ocho tonos de canto de órgano dal Cancionero de Upsala (1556). Bolonia: Ut Orpheus.

Boscán, J. (1543). Las obras de Boscán y algunas de Garcilaso de la Vega repartidas en quatro libros. Barcelona: Carlos Amorós.

Boscán, J. (1999). Obra completa. C. Clavería (Ed.). Madrid: Cátedra Letras Hispánicas.

Briquet, C. M. (1985). Les filigranes, 4 vols. Nueva York: Hacker Art Books.

Brown, H. M. (2000). A Bibliography. Instrumental Music Printed Before 1600. CambridgeLondon: Harvard University Press.

Brudieu, J. (1585). De los madrigales del muy reverendo Joan Brudieu, a quatro boces. Barcelona: Hubert Gotard.

Calahorra Martínez, P. (Ed.) (1980). Pedro Ruimonte. Parnaso español de villancicos y madrigales y villancicos a quatro, cinco y seys. Zaragoza: Institución "Fernando el Católico", Diputación de Zaragoza. 


\section{FRANCESC VillaNUEVA SERRANO}

Cerone, P. (1613). El Melopeo y Maestro. Nápoles: J. B. Gargano y L. Nucci.

Cerveró Martínez, F. J. (2017). Juan Arañés y su Libro Segundo De Tonos y Villancicos... con la cifra de la guitarra española a la usanza romana (Roma, Juan Bautista Robletti, 1624). (Tesis Doctoral). Valencia: Universitat Politècnica de València.

Christoforidis, M., \& Ruiz Jiménez, J. (1994). Manuscrito 975 de la Biblioteca Manuel de Falla: una nueva fuente polifónica del siglo XVI. Revista de Musicología, 17, pp. 205236.

Civil i Castellví, F. (Ed.) (1982). Cançoner de la Garrotxa. Gerona: Diputació de Girona.

Climent Barber, J. (1966). La música en Valencia durante el siglo XVII. Anuario Musical, 21, pp. 211-241.

Climent Barber, J. \& Piedra Miralles, J. (1977). Juan Bautista Comes y su tiempo. Estudio biográfico. Madrid: Comisaría Nacional de la Música.

DiFranco, R. A., Labrador Herraiz, J. J. \& Zorita, C. Á. (Eds.) (1989). Cartapacio de Francisco Morán de la Estrella. Madrid: Patrimonio Nacional.

Donato, B. (1550). Il primo libro di canzon Villanesche alla Napolitana a quatro Voci. Venecia: Antonio Gardane.

Dutton, B. (1990-1991). El Cancionero del siglo XV: 1360-1520, 7 vols. Salamanca: Universidad de Salamanca.

Etzion, J. (Ed.) (1996). El Cancionero de la Sablonara. Londres, Tamesis.

Ezquerro Esteban, A. (Ed.) (2007). Pedro Cerone: El Melopeo y Maestro, 2 vols. Barcelona: CSIC.

Fernández de Heredia, J. (1562). Las obras de don Ioan Fernandez de Heredia, assi temporales como espirituales. Valencia: Juan Mey.

Fernández de Heredia, J. (1955). Obras. R. Ferreres (Ed.). Madrid: Espasa-Calve.

Ferreira, M. P. (Ed.) (1989). Cancioneiro da Biblioteca Publia Hortensia de Elvas. Lisboa: Instituto Portugues do Património Cultural.

Frenk Alatorre, M. (1992). Diez cancioncitas populares en un manuscrito valenciano del siglo XVI. Nueva Revista de Filología Hispánica, 40, pp. 187-198. 
EL CANCIONERO MUSICAL DE GERONA:

MADRIGALES Y VILLANCICOS EN UNA NUEVA FUENTE HISPÁNICA DEL SIGLO XVI

Frenk Alatorre, M. (2003). Nuevo Corpus de la Antigua Lírica Popular Hispánica (siglos XV a XVII), 2 vols. México: D. F.: Universidad Nacional Autónoma de México, El Colegio de México, Fondo de Cultura Económica.

Frenk Alatorre, M., Labrador, J. J. \& DiFranco, R. (Eds.) (1996). Cancionero Sevillano de Nueva York. Sevilla: Universidad de Sevilla.

Fuenllana, M. (1554). Libro de música para vibuela intitulado Orphénica Lyra. Sevilla: Martín de Montesdeoca.

Furió, A. (1980). Orgue de Sueca (Valéncia). Orgues del País V alencià, XIII-XIV, pp. 3-44.

Gómez Gallego, A. (2015). La recepción de la lírica popular antigua en la obra del polifonista Juan Vázquez, 2 vols. (Tesis Doctoral). Badajoz: Universidad de Extremadura.

Gómez Muntané, M. C. (Ed.) (2003). Cancionero de Uppsala, 2 vols. Valencia: Generalitat Valenciana.

Goméz Muntané, M. C. (2011). The Cancionero Musical Valenciano in the Biblioteca Nacional in Madrid: A Preliminary Report. En K. Nelson (Ed.). Cathedral, City and Cloister: Essays on Manuscripts, Music and Art in Old and New Worlds (pp. 173-193). Ottawa: The Institute of Medieval Music.

Gómez Pintor, M. A. (2000). Navarro, Juan. En E. Casares Rodicio (Ed.). Diccionario de la Música Española e Hispanoamericana, vol. 7 (pp. 992-994). Madrid: Sociedad General de Autores y Editores.

González García, S. (2014). Estudio de las encuadernaciones originales datadas de la Colección de manuscritos árabes de la Biblioteca de la Escuela de Estudios Árabes de Granada. (Tesis Doctoral). Granada: Universidad de Granada.

Gorzanis, G. (1563). Il secondo libro de intabulatura di liuto. Venecia: Girolamo Scotto.

Guerrero, F. (1589). Canciones y villanescas espirituales a tres y a quatro y a cinco bozes. Venecia: Giacomo Vincenti.

Iglesias, A. L. (1992): Amargas horas de los tristes días en una inédita colección española de madrigales espirituales. En P. M. Cátedra García, y M. L. López-Vidriero Abello (Eds.). El libro antiguo español: Actas del Segundo Coloquio Internacional (Madrid) (pp. 263283). Salamanca: Universidad de Salamanca, Biblioteca Nacional de España, Sociedad Española de Historia del Libro. 


\section{FRANCESC VillaNUEVA SERRANO}

Iglesias, A. L. (1996). El Cancionero Musical del Museo Lázaro Galdiano. En A. Menéndez Collera \& V. Roncero López (Eds.). Nunca fue pena mayor (Estudios de Literatura Española en homenaje a Brian Dutton (pp. 449-488). Cuenca: Universidad de Castilla-La Mancha.

Iglesias, A. L. (1998). Andanzas y fortunas de algunos impresos musicales españoles del siglo XVI: Fuenllana y Pedro Guerrero. En M. I. Hernández González (Ed.). El libro antiguo español IV. Coleccionismo y Bibliotecas (Siglos XV-XVIII) (pp. 461-503). Salamanca: Ediciones Universidad de Salamanca, Patrimonio Nacional, Sociedad Española de Historia del Libro.

Kargel, S. (Ed.) (1578). Renovata cythara: Hoc est novi et commodissimi exercendae cytharae modi. Estrasburgo: Bernhard Jobin.

Kirk, D. (Ed.) (2006). Music for the Duke of Lerma: canciones and motets of four, five, and six voices: the music of Archivo de San Pedro de Lerma, ms. mus. 1. Arlington: Amherst Early Music.

Jacobs, C. (Ed.) (1978). Miguel de Fuenllana. Orphénica Lyra (Seville, 1554). Oxford: Clarendon Press.

Jambou, L. (1983). La Capilla de música de la Catedral de Sigüenza en el siglo XVI. Ordenación del tiempo musical litúrgico. Revista de Musicología, 6, pp. 271-298.

Joaquim, M. (Ed.) (1940). O Cancioneiro Musical e Poético da Biblioteca Públia Hortensia. Coimbra: Instituto para a Alta Cultura.

Labrador, J. J., DiFranco, R. \& Montero, J. (Eds.) (2006). Cancionero Sevillano de Toledo. Sevilla: Universidad de Sevilla.

Lee-Francis Askins, A. \& Sage, J. (1976). The Musical Songbook of the Museu Nacional de Arqueologia e Etnologia, Lisbon (ca. 1603). Luso-Brazilian Review, 13(2), pp. 129-137.

Lesure, F. (1960). Répertoire International des Sources Musicales. Recueils imprimés XVI $I^{\grave{ }}$-XVII ${ }^{\grave{e}}$ siècles, vol I. München-Duisburg: G. Henle Verlag.

Lewis, M. S. (2005). Antonio Gardano, Venetian Music Printer 1538-1569. A Descriptive Bibliography and Historical Study, volume 2: 1550-1559. Nueva York/Oxford: Routledge.

Limido, S. (1605). Regii Concenti Spirituali. Milán: Agostino Tradate.

Limido, S. (1624). Armonía spiritual. Madrid: Tipografía Regia. 
EL CANCIONERO MUSICAL DE GERONA:

MADRIGALES Y VILLANCICOS EN UNA NUEVA FUENTE HISPÁNICA DEL SIGLO XVI

Llorens Cisteró, J. M. (1987). La música española en la segunda mitad del siglo XVI: Polifonía, música instrumental, tratadistas. En J. López-Calo, J. I. Fernández de la Cuesta \& E. F. Casares Rodicio (Eds.). España en la Música de Occidente: actas del congreso internacional celebrado en Salamanca, 29 de octubre-5 de noviembre de 1985. Año Europeo de la Música (pp. 189-285). Madrid: Ministerio de Cultura, Instituto Nacional de las Artes Escénicas y de la Música.

Llorens Cisteró, J. M. (2002). Zorita, Nicasio. En E. Casares Rodicio (Ed.). Diccionario de la Música Española e Hispanoamericana. vol. 10 (pp. 1192-1193). Madrid: Sociedad General de Autores y Editores.

López-Calo, J. (2008). La Música en la Catedral de Valladolid, vol I, Catálogo del Archivo de Música (I), Volúmenes encuadernados. Valladolid: Ayuntamiento de Valladolid, Caja España.

Marín López, J. (2007). Un tesoro musical inexplorado: los libros de polifonía de la Catedral de Baeza. En M. Á. Moreno Moreno (Coord.). Estudios de Humanismo Español. Baeza en los siglos XVI y XVII (pp. 319-346). Baeza: Ayuntamiento de Baeza.

Martínez de la Rosa, F. (1834). Poética Española. París: Julio Didot.

Mazuela-Anguita, A. (2016). Polifonía, redes musicales y ceremonias rurales en los Pirineos Orientales a través de las crónicas de Honorat Ciuró (1612-1674). Revista de Musicología, 39(2), pp. 411-454.

Miranda, G. (Ed.) (1987). The Elvas Songbook. Neuhausen-Stuttgart: American Institute of Musicology, Hänssler-Verlag.

Montemayor, J. de (1558-1559). Los siete libros de la Diana. Valencia: Joan Mey.

Montemayor, J. de (1996). La Diana. [J. Montero (Ed.)]. Madrid: Crítica.

Morais, M. (Ed.) (1977). Cancioneiro Musical d'Elvas. Lisboa: Fundaçao Calouste Gulbenkian.

Morais, M. (Ed.) (1988). Cancioneiro Musical de Belém. Lisboa: Imprensa Nacional-Casa da Moeda.

Mota Murillo, R. (Ed.) (1980). Sebastián López de Velasco (1584-1659). «Libro de missas, motetes, salmos magnificas y otras cosas tocantes al culto divino», 2 vols. Madrid: Sociedad Española de Musicología.

Mudarra, A. (1546). Tres libros de música en cifra para vihuela. Sevilla: Juan de León. 


\section{FranCESC VillanUEVA SERRANO}

Núñez, H. (1555). Refranes, o proverbios en romance. Salamanca: Juan de Cánova.

Ochoa, E. de (Ed.) (1840). Tesoro de los romanceros y cancioneros españoles, históricos, caballerescos, moriscos y otros. Barcelona: Librería de los SS. A. Pons y compañía.

Ochsenkhun, S. (1558). Tabulaturbuch auf die lauten, von Moteten, Frantzö̈isischen, Welschen und Teütschen Geystlichen und Weltlichen Liedern. Heidelberg: Johan Kholen.

Olmos, Á. M. (2003). Aportaciones a la temprana historia musical de la capilla de las Descalzas Reales de Madrid (1576-1618). Revista de Musicología, XXVI(2), pp. 439-490.

Padilla, P. de (1582). Églogas pastoriles. Sevilla: Andrea Pescioni.

Pedrell, F. (1899). Libros de música españoles raros ó desconocidos (conclusión). Revista crítica de Historia y Literatura, IV(10), pp. 420-425.

Pedrell, F. (1907). Músics vells de la terra. Segona serie. Revista Musical Catalana, 37, pp. 1-4.

Pedrell, F. \& Anglés, H. (Eds.) (1921): Els madrigals i la missa de difunts d'en Brudieu. Barcelona: Institut d'Estudis Catalans.

Prats Redondo, C. (2000). Murcia. En E. Casares Rodicio (Ed.). Diccionario de la Música Española e Hispanoamericana, vol. 7 (pp. 889-894). Madrid: Sociedad General de Autores y Editores.

Puentes-Blanco, A. (2018). Música y devoción en Barcelona (ca. 1550-1626): Estudio de libros de polifonía, contextos y prácticas musicales. (Tesis Doctoral). Barcelona: Universitat de Barcelona.

Pujol, E. (Ed.) (1949). Alonso Mudarra. Tres libros de música en cifra para vihuela. Barcelona: CSIC, Instituto Español de Musicología.

Querol Gavaldá, M. (Ed.) (1949-1950). Cancionero musical de la Casa de Medinaceli (Siglo XVI), 2 vols. Barcelona: CSIC, Instituto Español de Musicología.

Querol Gavaldá, M. (Ed.) (1970). Música barroca española, vol. 1. Polifonía profana (Cancioneros españoles del siglo XVII). Barcelona: CSIC, Instituto Español de Musicología.

Querol Gavaldá, M. (Ed.) (1981). I. Madrigales españoles inéditos del siglo XVI. II. Cancionero de la Casanatense. Barcelona: CSIC, Instituto Español de Musicología. 


\section{El CANCIONERO MUSICAL DE GERONA:}

MADRIGALES Y VILLANCICOS EN UNA NUEVA FUENTE HISPÁNICA DEL SIGLO XVI

Querol Gavaldá, M. \& García Julbe, V. (Eds.) (1955 y 1957). Francisco Guerrero (1528-1599).

Canciones y villanescas espirituales, 2 vols. Barcelona: CSIC, Instituto Español de Musicología.

Querol Rosso, L. (Ed.) (1980). Cancionero de Uppsala. Transcripción de Rafael Mitjana. Madrid: Instituto de España.

Restrepo, M. (2009). A genre transplanted: The madrigal in Spanish collections of printed music (1536-1614), 2 vols. (Tesis Doctoral). Waltham: Brandeis University.

Riosalido, J. (Ed.) (1983). El Cancionero de Uppsala. Reproducción facsimil y ensayo. Madrid: Instituto Hispano-Árabe de Cultura.

RISM (2021). Répertoire International des Sources Musicales on-line [versión electrónica]. Recuperado de http://www.rism.info/es/home.html.

Rodríguez García, E. (2008). El repertorio musical de la colegiata de Orihuela a través de un inventario de mitad del siglo XVI. Revista de Musicología, 63, pp. 3-24.

Rodríguez-Moñino, A. (Ed.) (1954). Flor de romances y glosas, canciones y villancicos (Zaragoza: Juan Soler, 1578). Valencia: Castalia.

Ros-Fábregas, E. y Marín-López, J. (2020a). Navarro, Juan. En E. Ros-Fábregas (Ed.). Books of Hispanic Polyphony. Recuperado de https://hispanicpolyphony.eu/person/13472.

Ros-Fábregas, E. y Marín-López, J. (2020b). Ortega, Pedro. En E. Ros-Fábregas (Ed.). Books of Hispanic Polyphony. Recuperado de https://hispanicpolyphony.eu/person/13858.

Rotta, A. (1546). Intabolatura de lauto di lo eccellentissimo musicho messer Antonio Rotta di recercari motetti, balli, madrigali, canzon francese da lui composti, \& intabulati, \& novamente posti in luce. Libro primo. Venecia: [Girolamo Scotto].

Ruimonte, P. (1614). Parnaso español de villancicos y madrigales y villancicos a cuatro, cinco y seys. Amberes: Pierre Phalése.

Ruiz Jiménez, J. (Ed.) (1999). Cinco canciones para ministriles. Francisco Guerrero (1528-1599). Madrid: Fundación Caja Madrid, Editorial Alpuerto.

Schmid, B. (Ed.) (1577). Zwei Bücher. Einer Neuen Kunstlichen Tabulatur auff Orgel und Instrument. Estrasburgo: Bernhart Jobin. 


\section{FRANCESC VilLANUEVA SERRANO}

Selfa Sastre, M. (2010). Onomàstica de la Bisbal d'Empordà. Barcelona: Institut d'Estudis Catalans.

Stevenson, R. (1993). La música en las Catedrales españolas del Siglo de Oro. Madrid: Alianza Editorial.

Torrente, Á. (2016). Tonos, bailes y guitarras en los ámbitos privados. En Á. Torrente (Ed.). Historia de la Música en España e Hispanoamérica, vol 3. La música en el siglo XVII (pp. 193-275). Madrid: Fondo de Cultura Económica.

Valderrábano, E. de (1547). Libro de música de vihuela intitulado Silva de Sirenas. Valladolid: Francisco Fernández de Córdoba.

Valladares Reguero, A. (1994). Diez sonetos de Pedro de Padilla atribuidos a Quevedo. Precisiones sobre un problema no suficientemente esclarecido. Revista de la Facultad de Humanidades de Jaén, 3(1), pp. 79-94.

Valls, O. (1965). La filigrana del peregrino. Investigación y Técnica del papel, 6, pp. 631-643.

Valls, O. (1970). Paper and watermarks in Catalonia, 2 vols. Amsterdam: The Paper Publications Society (Labarre Foundation).

Varios (1552). Hortus musarum in quo tanquam flosculi. Lovaina: Pierre Phalèse.

Varios (1553). Horti musarum secunda pars, continens selectissima quaedam ac iucundissima carmina testudine simul et voce bumana, vel alterius instrumenti musici admmiculo modulanda. Lovaina: Pierre Phalèse.

Varios (1556). Villancicos de diversos autores, a dos, y a tres, y a quatro, y a cinco bozes, agora nuevamente corregidos. Venecia: Geronimo Scotto.

Varios (1563). Theatrum musicum in quo selectissima optimorum quorumlibet autorum ac excellentissimorum artificum cum veterum tum etiem novorum carmina summa diligentia ac industria ezpressa oculis proponuntur. Lovaina: Pierre Phalèse.

Varios (1568). Luculentum theatrum musicum, in quo (demptis vetustate tritis cantionibus) selectissima optimorum quorumlibet autorum, ac excellentissimorum artificum tum veterum, tum praecipuè recentiorum carmina. Lovaina: Pierre Phalèse.

Varios (1570). Hortulus cytharae, in duos distinctos libros, quorum prior cantiones musicas longe pulcherrimas, passomezo, paduanas, galliardes, alemandes, branles, ad usum vulgaris cythara. Lovaina: Pierre Phalèse y Jean Bellère. 


\section{El CANCIONERO MUSICAL DE GERONA:}

MADRIGALES Y VILLANCICOS EN UNA NUEVA FUENTE HISPÁNICA DEL SIGLO XVI

Varios (1571). Theatrum musicum, longe amplissimum cui (demptis quae vetustate vilverant) authorem praestantiss. tum veterum tum recentiorum carmina selectissima sunt inserta. Lovaina: Pierre Phalèse y Jean Bellère.

Varios (1572). Das Erste Buch Newverlessner Fleissiger ettlicher viel Schöner Lautenstück, von artlichen, Fantaseyen, lieblichen Teütschen, Frantrösischen unnd Italiänischen Liedern künstlichen Lateinischen Muteten, mit vier und fünff stmmen, Auch lustigen allerhand Passomezen. Estrasburgo: Bernhart Jobin.

Varios (1574). Thesaurus musicus continens selectissima Alberti Ripae, Valentini Bacfarci et aliorum praestantissimorum carmina ad usum chelys, vel testudinis accomodata. Lovaina: Pierre Phalèse y Jean Bellère.

Varios (1578). Flor de romances y glosas, canciones y villancicos. Zaragoza: Juan Soler.

Varios (1582). Hortulus citharae, vulgaris continens optimas fantasias, cantiones que musicas pulcherrimas, et passomezos in varios tonos concinné variatos atque deductos. Amberes: Pierre Phalèse y Jean Bellère.

Vázquez, J. (1551). Villancicos $i$ canciones, a tres y a quatro. Osuna: Juan de León.

Vázquez, J. (1560). Recopilación de sonetos y villancicos a quatro y a cinco. Sevilla: Juan Gutiérrez.

Vásquez, J. (1995). Villancicos i canciones. E. A. Russell (Ed.). Madison: A-R Editions.

Vega, G. de la (2004). Obra completa. G. Suazo Pascual (Ed.). Madrid: Edaf.

Villanueva Serrano, F. (2019). O soberana luz: a spiritual madrigal and a Mass for Philip IV, monarch of the Hispanic kingdoms. Early Music, 47(3), pp. 307-332.

Villanueva Serrano, F. (2021). Reconstruint dos villancets del Renaixement hispà: Puix Fortuna m'ba llevat i Quien a dos amores ama. En A. Ezquerro \& L. A. González Marín (Coords.). Estudios sobre Recuperación de Patrimonio Musical Histórico. Scripta musicologica en torno a la figura del Dr. José V. González Valle, vol. I (pp. 427-459). Valencia: Tirant Humanidades.

Vreedman, S. (1568). Nova longeque elegantissima cithara ludenda carmina, cum Gallica tum etiam Germanica: fantasie item, passomezi, Gailliarde, Branles, Almanes, etc. Lovaina: Pierre Phalèse.

Waissel, M. (Ed.) (1573). Tabulatura continens insignes et selectissimas quasque cantiones, quatuor, quinque et sex vocum, testudini aptatas. Frankfurt an der Oder: Johannes Eichorn. 
FranCESC VillanUEVA SERRANO

APÉNDICE 1

Estructura y contenidos del CMG

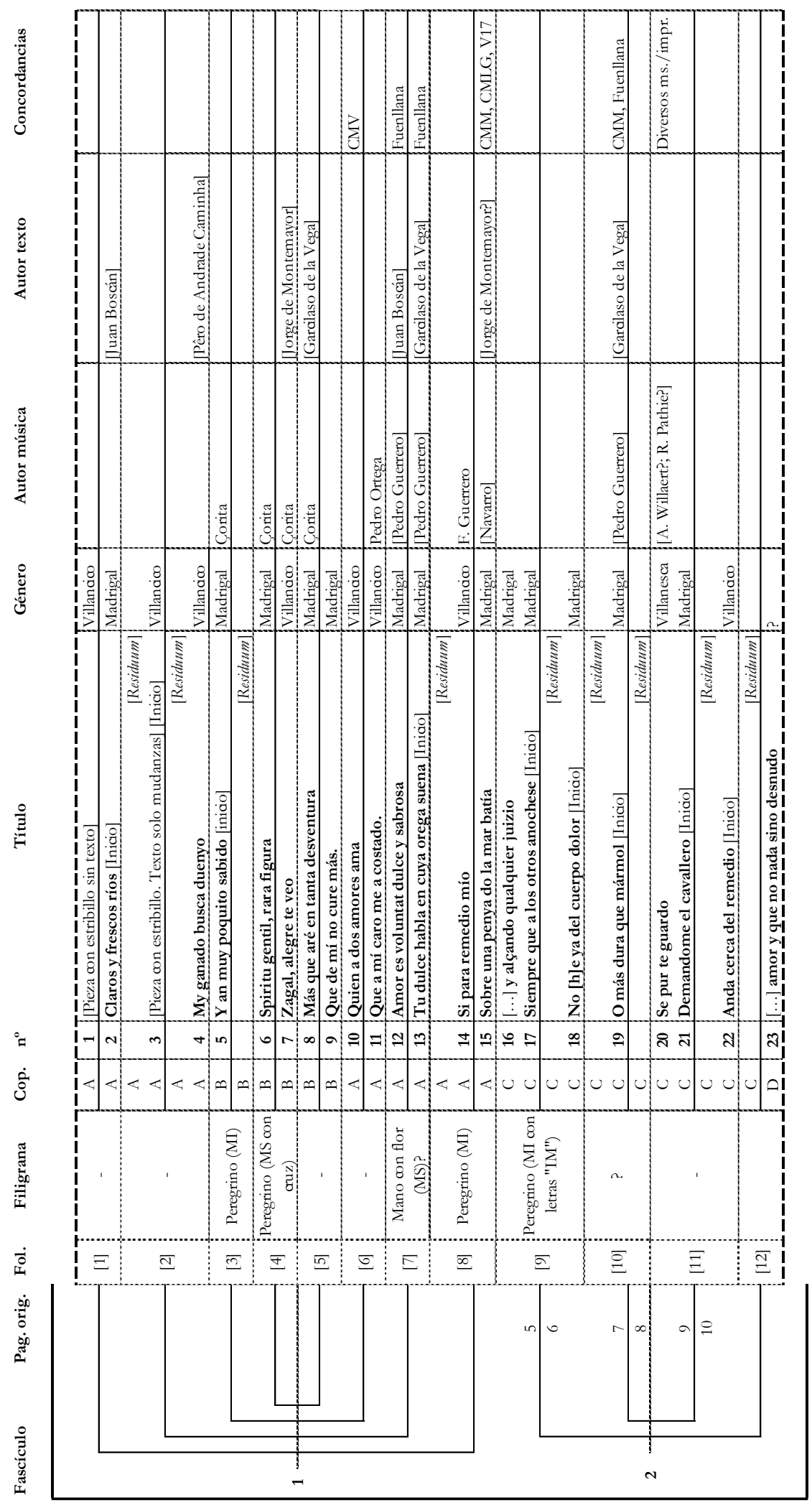




\section{APÉNDICE 2}

\section{Notas a la poesía y la música del CMG}

\section{Criterios de transcripción de la poesía}

Se ha respetado, en general, la ortografía del original aunque, para facilitar su lectura, se han efectuado las siguientes modificaciones:

- Resolución de las abreviaturas.

- Normalización de mayúsculas según la ortografía actual.

- Separación de palabras según la ortografía actual.

- Normalización según la ortografía actual de i-j y u-v, así como c-ç ante a, o, u.

- Simplificación de las dobles consonantes al principio de palabra.

- Uso del apóstrofe (') para señalar elisiones.

- Añadido de signos de puntuación.

Asimismo, se han adoptado las siguientes convenciones generales:

- [texto]: restitución o reconstrucción del texto.

- [texto]: comentarios del editor.

- [...]: texto ilegible o pérdida del texto.

- (sic): textual. Expresión anterior defectuosa.

- //: cambio de página.

1.

f. $[1 \mathrm{r}]$

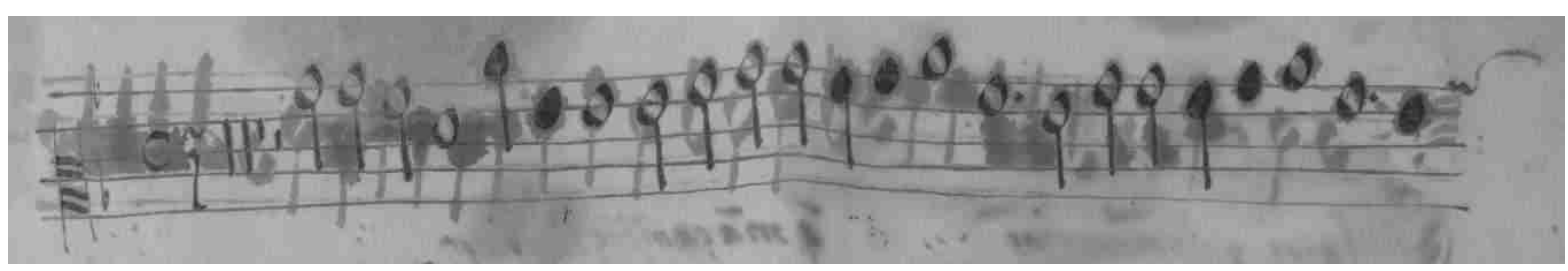

Poema: Sin texto.

Música: Anónima.

Anotaciones: "Buelta" antes de las coplas. "Riera de la Visbal" a pie de página. 
2.

ff. [1v]-[2r]

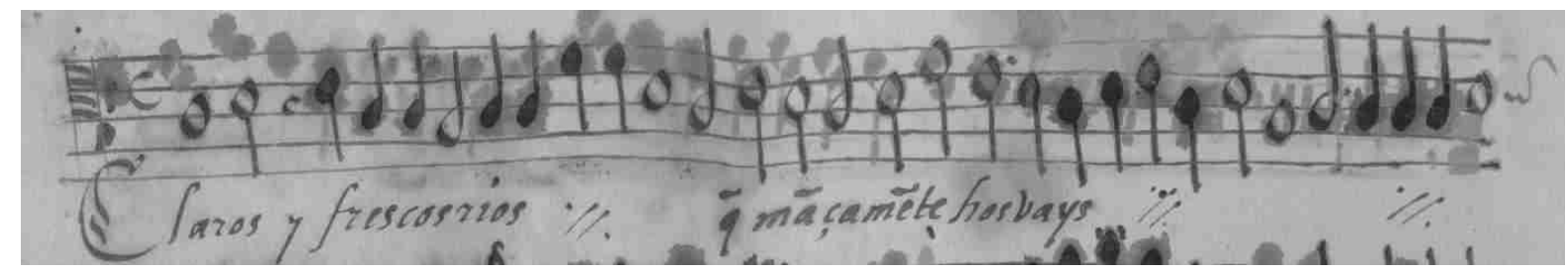

Poema: [uan Boscán (*1487-1492; †1542)].

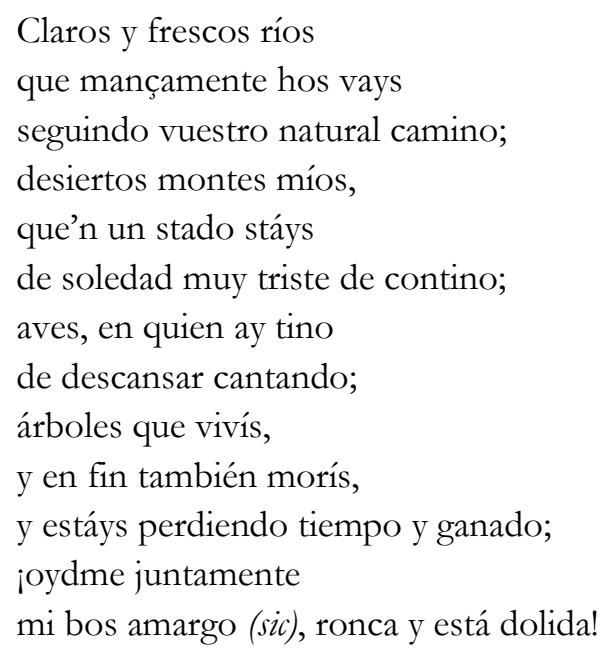

Primera estrofa de la Canción XLVIII publicada por vez primera en Boscán, 1543, f. 30r. Edición en Boscán, 1999, pp. 148-149: “Claros y frescos ríos / que mansamente vais / siguiendo vuestro natural camino; / desiertos montes míos, / que’n un estado estáis / de soledad muy triste, de contino; / aves en quien ay tino / de descansar cantando; / árboles que bivís, / y en fin también morís, / y estáis perdiendo a tiempos y ganando, / oídme juntamente / mi voz amarga, ronca y tan doliente".

Música: Anónima.

No concuerda con otras dos versiones musicales conservadas del mismo poema:

- CMM, ff. 4v-5r. Anónimo a 3 voces. Querol Gavaldá, 1949, vol. I, pp. 16, 34 (estudio), 9-10 (edición).

- Mudarra, 1546, libro III, f. [21r]-[23r]. Pujol, 1949, pp. 48, 96 (estudio), 94-95 (edición). Brown, 2000, nº154614. Lesure, 1960, nº 154634. 
3.

ff. $[2 \mathrm{r}]-[2 \mathrm{v}]$

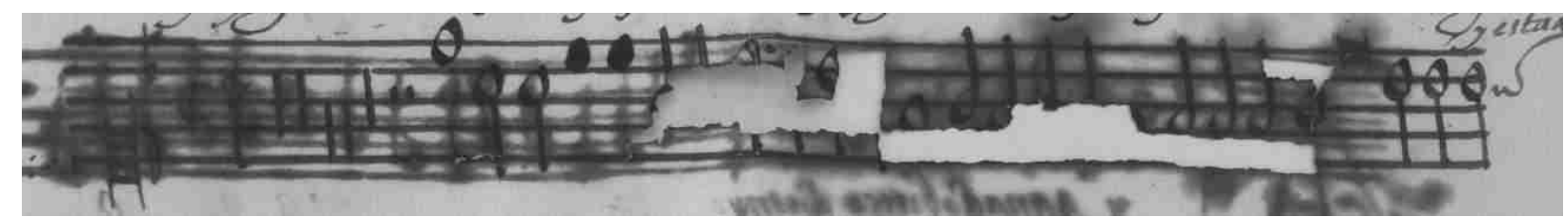

Poema: Anónimo.

[Estribillo sin texto]
Buelta

¿Qué remedio, qué favor

podrá valerme, pastores?

Un villancico de un manuscrito parisino lleva estos dos versos como primera mudanza (Martínez de la Rosa, 1834, p. 165). También fue editado sin identificación de la fuente en Ochoa, 1840 , p. 529.

Música: Anónima.

Anotaciones: "Tenor", al principio (f. [2r]) y antes de las coplas (f. [2v]). "Buelta" antes de las coplas (f. $[2 \mathrm{r}])$.

4.

f. $[2 \mathrm{v}]$

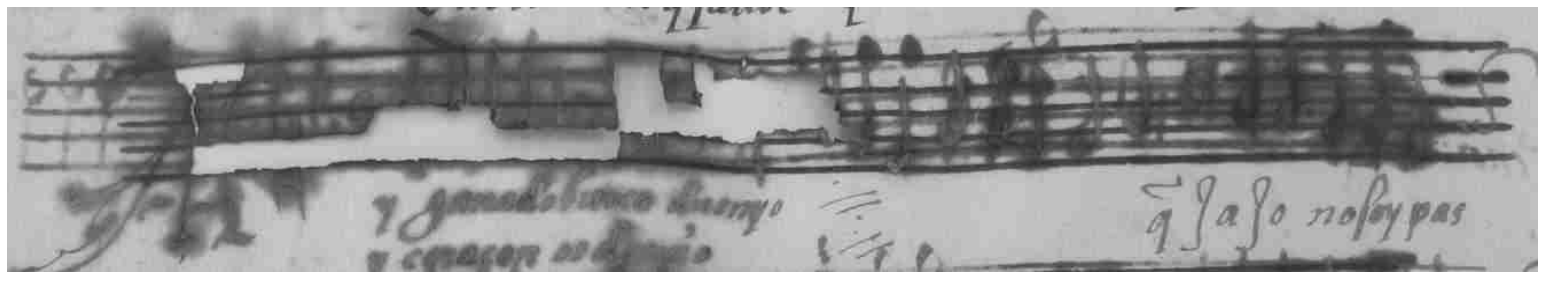

Poema: [Pêro de Andrade Caminha (*1520c; †1591)].

Mi ganado busca duenyo
que jo ja no soy pastor
d'oveyas sinó de amor.
Buelta.
[Mudanzas sin texto]
y coraçón os desvío
que jo ja no soy pastor
d'oveyas sinó de amor.


El estribillo de este villancico es atribuido a Caminha en: Biblioteca Nacional de Lisboa, COD 6383-84, vol I, f, 161r; British Library, Add. Mss. 33791, f. 264v; Anastácio, 1998, pp. LXXV, 384, 1213.

Música: Anónima.

Anotación: "Buelta" antes de las coplas.

5.

ff. $[3 \mathrm{r}]-[3 \mathrm{v}]$

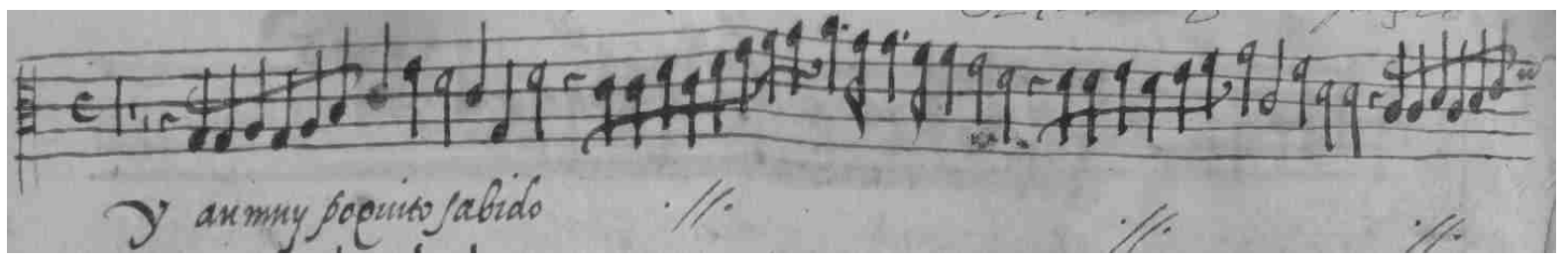

Poema: Anónimo.
Lugar, tiempo y ventura
muchos ay que l'an tenido
$\mathrm{Y}$ an muy poquito sabido
gosar de la coyuntura.

El estribillo fue publicado en Varios, 1578. Edición en Rodríguez Moñino, 1954, p. 184: "El lugar, tiempo y ventura / muchos hay que l'an tuvido / y muy pocos han sabido / gozar de la coyuntura". Glosada en las comedias La obediencia laureada (1615), El poder vencido y amor premiado (1618) y La venganza venturosa (1618) de Lope de Vega (*1562; †1635). Otras concordancias menores en Alín \& Barrio Alonso, 1997, p. 201.

Música: "Çorita" [Nicasi Sorita].

\section{6.}

f. $[4 \mathrm{r}]$

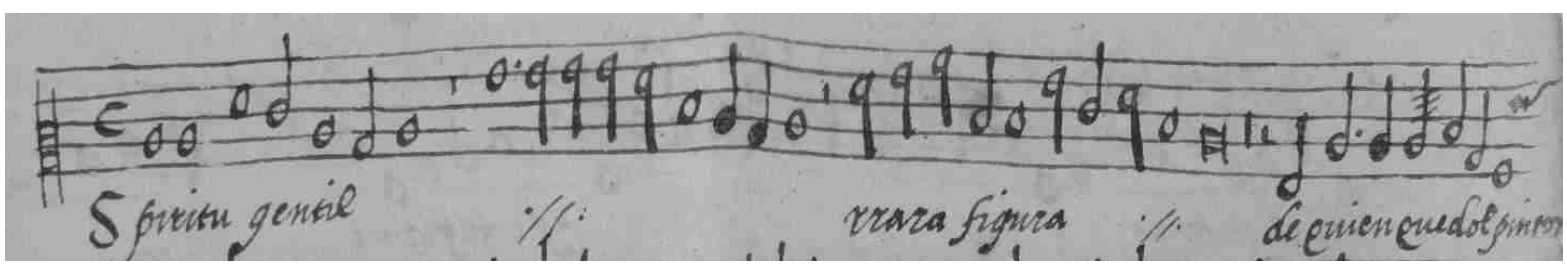

Poema: Anónimo. 


\section{EL CANCIONERO MUSICAL DE GERONA:}

Spíritu gentil, rara figura

de quien quedo'l pintor muy satisfecho, pues puso en vuestro cuerpo y en el pecho dos mil dotes de saber y hermosura.

Que pudo ya pintar más la natura, pues tuvo quanto pudo ya en vos echo, mira[d] que tal os hizo que so[s]pecho que atónita (sic) quedó de vuestra hechura.

Podría tratarse de los dos cuartetos de un soneto. El primer verso es similar al que inicia un soneto de Pedro de Padilla (*1540; †1599p) de semejante carácter amoroso ("Spíritu gentil, rara belleza”). Padilla, 1582, f. 242r. Valladares Reguero, 1994, pp. 79-93.

Música: "Çorita" [Nicasi Sorita].

7.

f. $[4 v]$

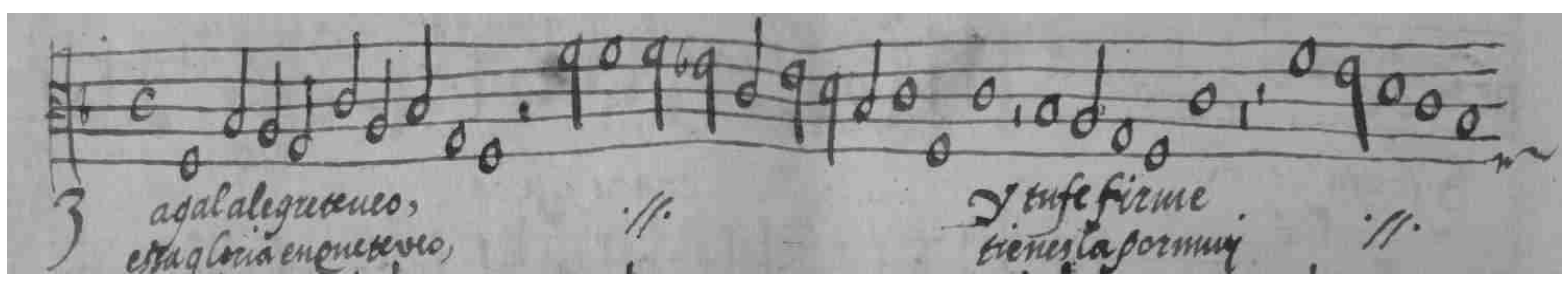

Poema: [Jorge de Montemayor (*1520c; †1561c)].

-Zagal, alegre te veo,

$\mathrm{y}$ tu fe firme y segura.

-Cortome Amor la ventura

a medida del deseo.

Buelta.

- ¿Qué deseaste alcanzar

que tal contento te diese?

-Querer a quien me quisiese;

que no ay más que desear.

-Esta gloria en que te veo

tiénesla por muy segura.

-No me l'a hado ventura

por aburlar al deseo. 


\section{FranCESC VillanUeVA SERRANo}

Estribillo y primera copla del canto de los pastores Silvano y Selvaggia, acompañados por la zampoña de Diana, del libro VI de Los siete libros de la Diana (Montemayor, 1558-1559). Edición en Montemayor, 1996, pp. 256-257. También figura en el manuscrito Bibliothèque Nationale de France, Espagnol, 307, f. 306v y en el Cancionero Sevillano de Nueva York (Hispanic Society, sign. B2486, f. 272 (282r)). Edición en Frenk Alatorre, Labrador \& DiFranco, 1996, p. 366.

Música: "Çorita" [Nicasi Sorita].

Anotaciones: “Tertio", al principio. "Buelta” después de las coplas.

8.

f. $[5 \mathrm{r}]$

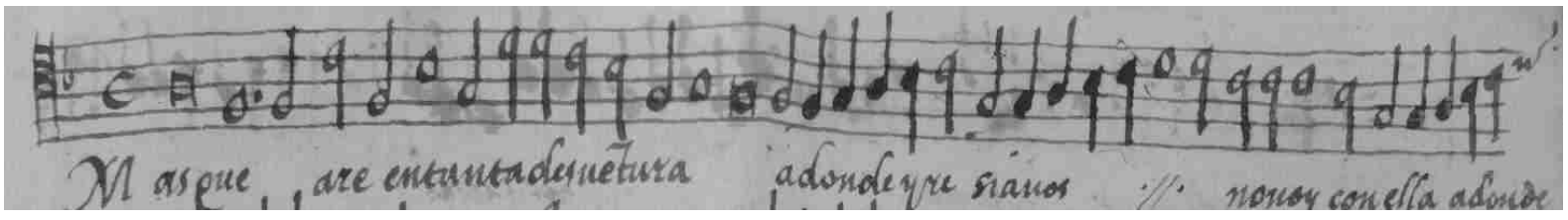

Poema: [Garcilaso de la Vega $(* 1499 ; \nmid 1536)]$.

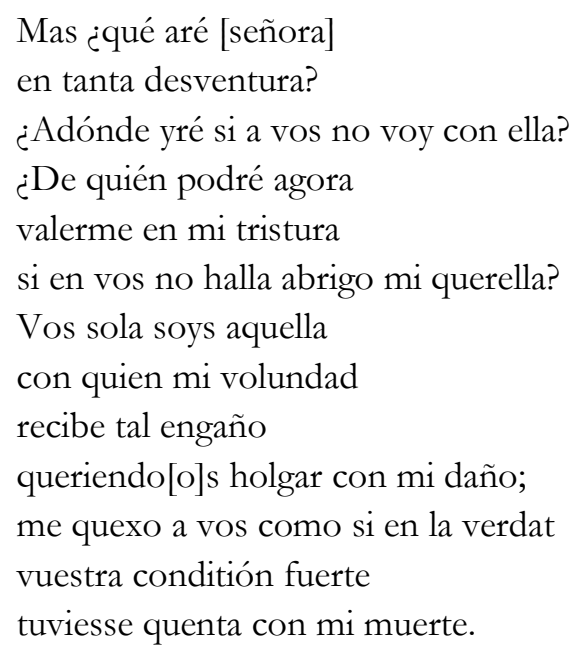

Segunda estancia de la Canción II, escrita entre 1526 y 1532 y publicada por primera vez en Boscán, 1543, f. 172r. Edición en Vega, 1994, pp. 165.

Música: "Çorita" [Nicasi Sorita].

Anotación: "Finis" a pie de página. 
9.

f. $[5 \mathrm{v}]$

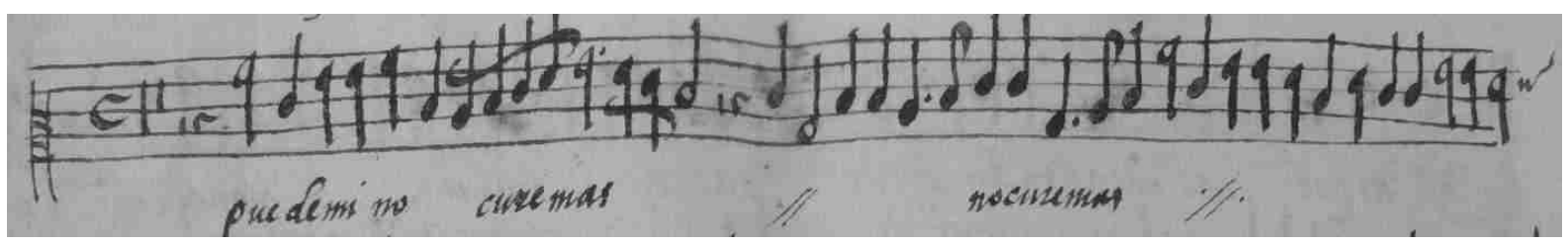

Poema: Anónimo.

[Pausas musicales] que de mí no cure más;

ve y dile que de mí no cure más,

y dirle as que de mí no cure más.

Versos emparentados con los dos finales del estribillo de una canción anónima en: British Library, Ms. Add. 33382, ff. 184r-184v (Dutton, 1990, vol. I, p. 345, LB2-183, ID2292): "Si alguna fasta aquí / por servidor me tenía / dezitle de parte mía / que no cure más de mí”; Biblioteca Estense de Módena, a.R.8.9, f. 106v (Dutton, 1990, vol. I, p. 425, ME1-108, ID2292): "Si alguna fasta aquí / por servidor me tenía / dezilde de parte mía / que non cure mas de mí”.

Música: Anónima.

Anotación: “Tenor", al principio.

10.

f. [6r]

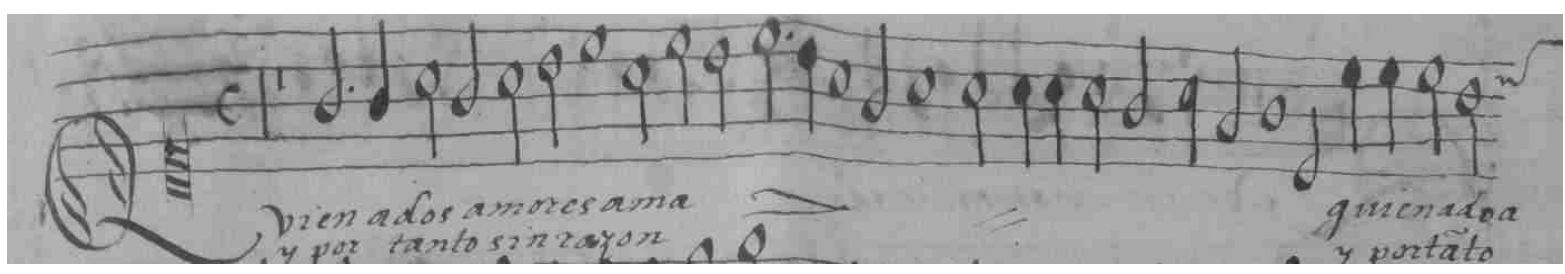

Poema: Anónimo.

Quien a dos amores ama a traición le saquen el alma.

Buelta.

Quien a dos amores ama

dentro de su coraçón,

a traición le saquen el alma,

por justicia y coraçón. 


\section{FranCESC VillanUEVA SERRANO}

Y por tanto, sin razón, a traición le saquen el alma.

Frenk Alatorre, 2003, vol. I, p. 1462.

Concordancias con:

- Coloquio en el cual se remeda el uso, trato y pláticas que las damas de Valencia acostumbran hazer y tener en las visitas que se hazen unas a otras, publicado en Fernández de Heredia, 1562, f. 131. Edición en Fernández de Heredia, 1955, p. 156.

- Núñez, 1555, f. 112r.

- Horozco, Sebastián de: Recopilación de refranes y adagios comunes y vulgares de España, la maior y más copiosa que hasta ahora se a hecho, Biblioteca Nacional de España, ms. 1849, f. 185v.

- Ensalada Filis, Angelia y Jacinta, publicada en Balvas Barona, 1627, f. 100v.

- Cancionero Sevillano de Nueva York (Hispanic Society, sign. B2486, f. 198v). Edición en Frenk Alatorre, Labrador \& Difranco, 1996, n 386.

- Biblioteca del Palacio Real de Madrid, ms. 1580, f. 176.

- Cartapacio de Morán de la Estrella (Biblioteca del Palacio Real de Madrid, ms. 531), f. 43v. Edición en DiFranco, Labrador Herraiz \& Zorita, 1989, nº 223.

Música: Anónima.

Concordancia con:

- CMV, ff. 43v-44v. Dos partes diferentes notadas en clave de G2 de la misma obra musical, no coincidentes con el del CMG. El texto del estribillo es el mismo pero no el de las mudanzas (Frenk Alatorre, 1992; Gómez Muntané, 2011).

Anotaciones: "Tenor" al principio. "Buelta" antes de las coplas.

11.

f. $[6 \mathrm{v}]$

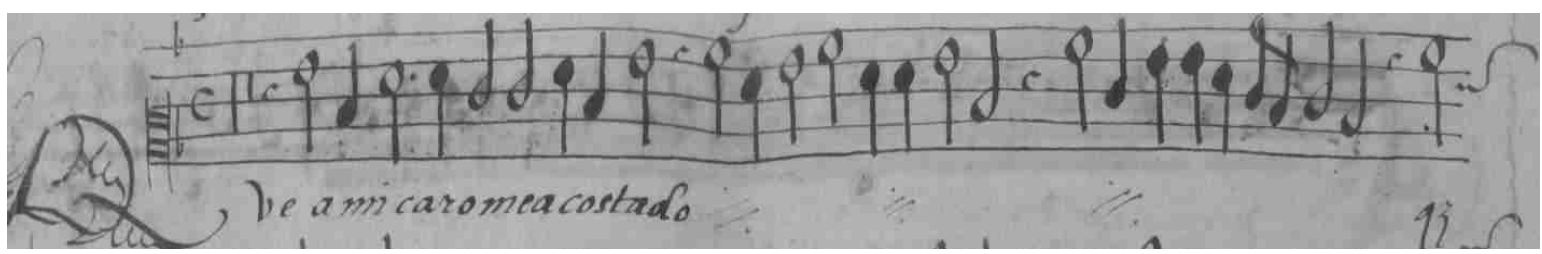

Poema: Anónimo.

- [Pausas $]$

Que a mí caro me ha costado.

¿Cómo te va Gil con amores?

Dímelo amigo amado, 


\section{El CANCIONERO MUSICAL DE GERONA:}

que a mí caro me ha costado.

Buelta.

-Amigo puedes llamarme;

amado nunca lo he sido;

$\mathrm{y}$ aun d'esso me ha venido

tanta razón de quexarme.

$-[$ Pausas $]$

Que a mí caro me ha costado

¿Cómo te va Gil con amores?

Dímelo amigo amado,

que a mí caro me ha costado.

Música: "Pedro Ortega".

Anotación: "Tenor", al principio. "Buelta" antes de las coplas.

12.

f. $[7 \mathrm{r}]$

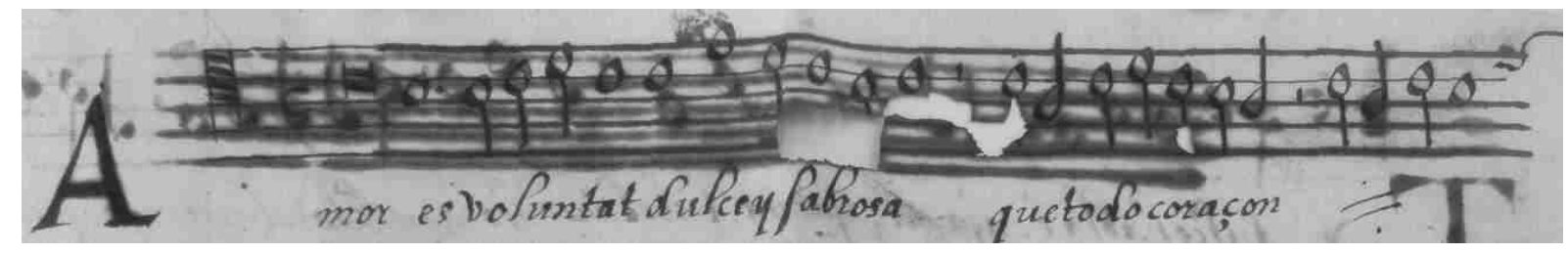

Poema: [Juan Boscán (*1487-1492; †1542)].

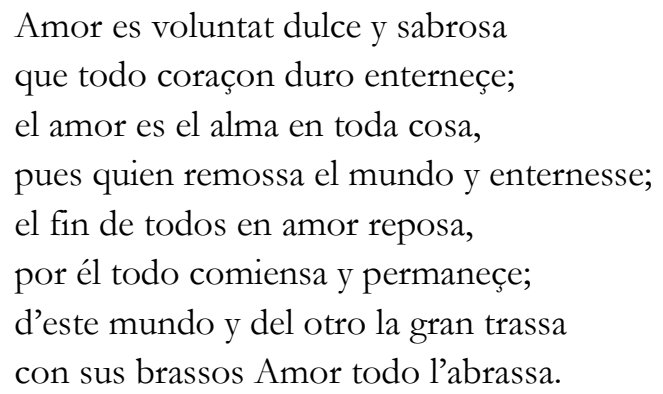

Octava real de Octava rima (vv. 537-544) publicado en Boscán, 1543, f. 152r. Edición en Boscán, 1999, p. 392.

Música: [Pedro Guerrero].

Pudo formar parte del impreso titulado Sonetos \& Madrigais difíciles. Pedro Guerrero, a 3, hoy considerado perdido (Iglesias, 1998, pp. 461-503). 


\section{FranCESC VilLANUEVA SERRANO}

Concordancia con:

- Fuenllana, 1554, ff. 128v-129v. Brown, 2000, no15543. Lesure, 1960, nº155432. Atribuido a Pedro Guerrero.

13.

ff. $[7 \mathrm{v}]-[8 \mathrm{r}]$

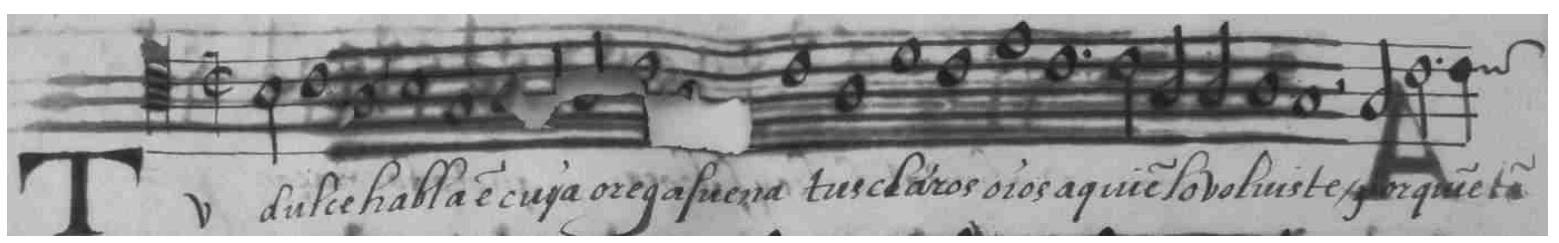

Poema: [Garcilaso de la Vega (*1499; †1536)].

Tu dulce habla, ¿ंen cuya orega suena?

Tus claros ojos, ¿a quién lo[s] volviste? ¿Por quién tan sin respeto me trocaste?;

Tu quebrantada fe, ¿do la pusiste?

¿qual el cu[e]llo, que como en cadena de tus hermosos brassos añudastes?

No hay coraçón que baste, aunque fuesse de piedra, viendo mi amada yedra, de mí arencada, en otro muro assida, y mi parra en otro olmo entretexida que no se esté con lantos deshaziendo hasta acabar la vida.

¡Salid sin duelo lágrimas corriendo!

Silva de Salicio en la Égloga al visorey de Nápoles (Égloga I). Edición en Vega, 2004, p. 228. Publicada por vez primera en Boscán, 1543, f. 192v.

Música: [Pedro Guerrero].

Segunda parte del madrigal $O$ más dura que mármol. (véase n¹9). Pudo formar parte del impreso titulado Sonetos \& Madrigais difíciles. Pedro Guerrero, a 3, hoy considerado perdido (Iglesias, 1998, pp. 461-503).

Concordancia con:

- Fuenllana, 1554, f. 124v-125v. Brown, 2000, n¹5543. Lesure, 1960, nº155432. Atribuido a Pedro Guerrero. 
14.

f. $[8 \mathrm{r}]$

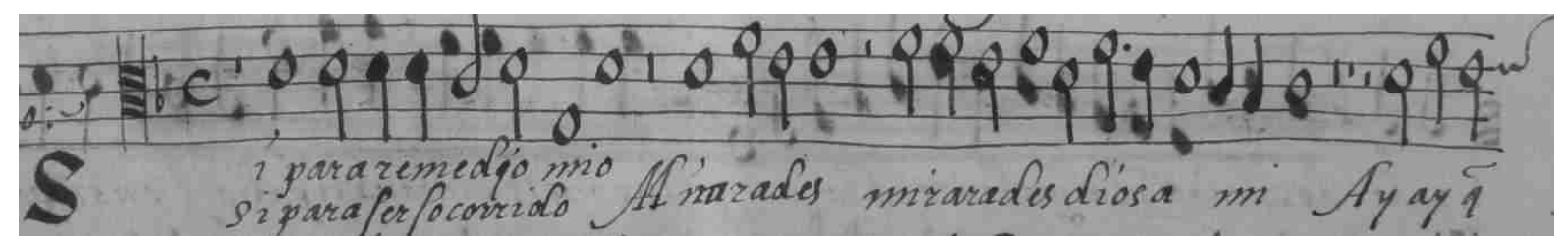

Poema: Anónimo.
Si para remedio mío
mirárades Dios a mí,
ay, ay qué fuera de mí.
Siendo vos el offendido
y yo perverso offensor,
¿qué fuera de mí, Señor
sin el bien que habéys traido?
Si para ser socorrido
mirárades Dios a mí,
ay, ay fuera de mí.

Música: "F. Guerrero" [Francisco Guerrero].

15.

f. $[8 \mathrm{v}]$

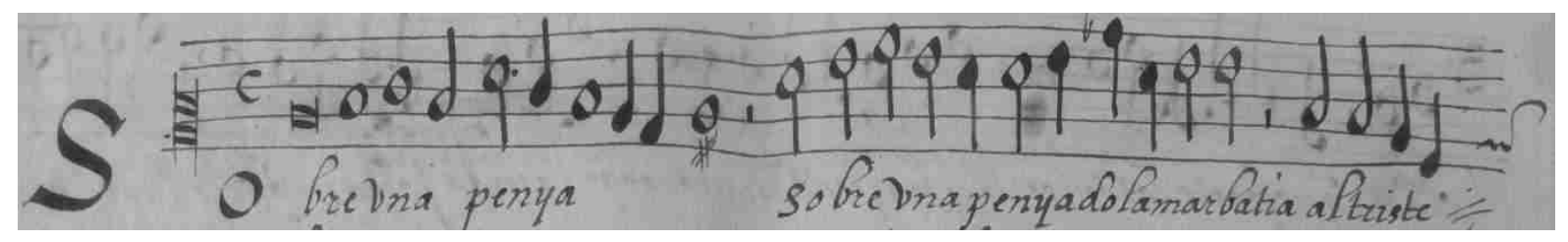

Poema: Anónimo [Jorge de Montemayor? (*1520c; †1561c)?].

Sobre una penya do la mar batía, al triste lusitano vi acentado, ajeno de plazer y acompanyado de soledad que l'alma l'encendía. Los ojos levantaba si podía, en su patria los pone'l desditxado, 


\section{FraNCESC VilLANUEVA SERRANO}

y al enemigo viento y mar ayrado

en bos, cansado y triste, ansí dezía:

O mar, ci el de mis ojos, //

[incompleto].

Soneto atribuible a Jorge de Montemayor. Un soneto de Gutierre de Cetina (Con ansia que del alma le salía) y otro de Diego Hurtado de Mendoza (En la ribera de la mar sentada) guardan alguna similitud. El último verso es usado posteriormente por Miguel de Cervantes en Los baños de Argel. (Iglesias, 1996, p. 466).

Música: [[Juan] Navarro].

Segunda sección incompleta.

Concordancias con:

- CMM, ff. 67v-68r. Madrigal a 4 en dos partes atribuido a "Navar[r]o". La parte del CMG se corresponde con la etiquetada como "altus" en la edición del CMM (Querol Gavaldá, 1949, vol I, nº45, pp. 18, 49 (estudio), 106-109 (edición)).

- CMLG, ff. 17v-18r. Solo conservada parte de tiple primero. Atribuida a "Nabarro" (Iglesias, 1996, pp. 465-466).

- E- $V$, ms. 17, ff. 3v-5r. Solo conservada la parte de alto. Atribuida a "Navarro" (Anglés, 1948, p. 83). Iglesias, 1996, p. 466.

En E-PAbm, B89-A-18 [olim Madrid 13231 o R. 6828/860] (Tonos castellanos), ff. 61v-62r se conserva una pieza anónima a 3 voces sobre un soneto pastoril que comienza por el mismo primer verso, aunque sin concordancias musicales con el CMG. Querol Gavaldá, 1970, pp. 16, 35-36; Querol Gavaldá, 1981, pp. 64-66; Arriaga y Frenk, 2017, pp. 224-227.

16.

f. $[9 \mathrm{r}]$

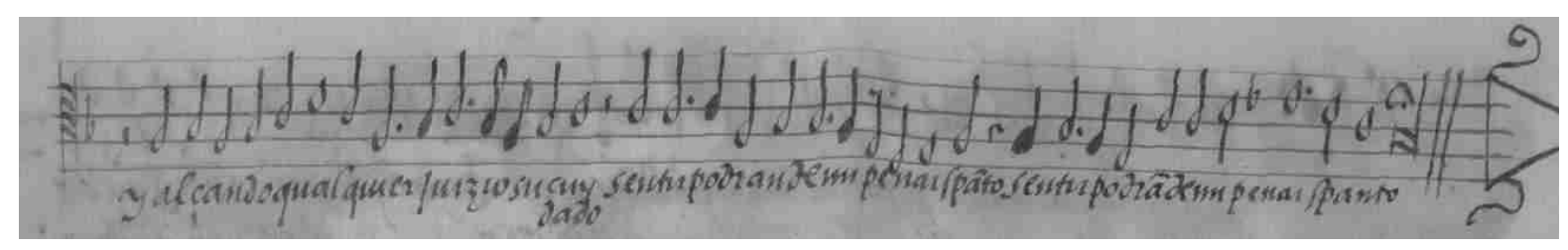

Poema: Anónimo.

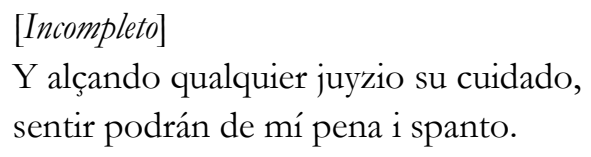

Música: Anónima.

Incompleta. 
17.

ff. $[9 \mathrm{r}]-[9 \mathrm{v}]$

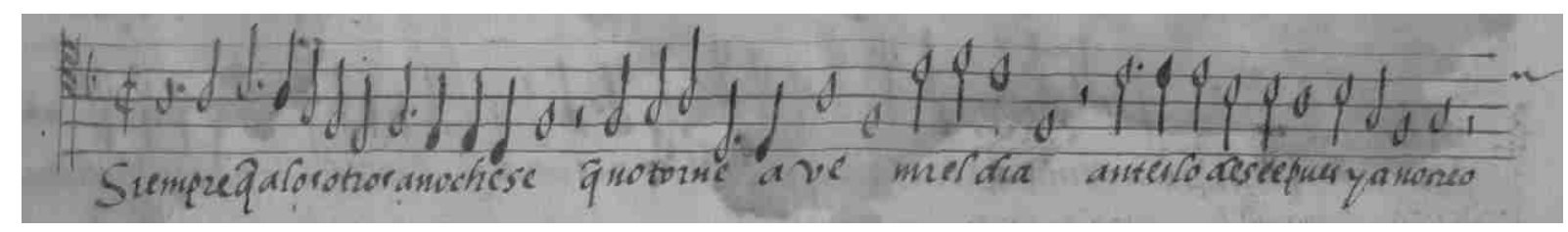

Poema: Anónimo.

Siempre que a los otros anochese, que no torne a venir el día; antes lo desee pues ya no creo podré gozar del sol que resplandese. La noche para mí ya s'escuresce, el día claridat nunca la veo; ¡triste yo!, ¡triste yo! pues sentí sino pensar o cosa qu'entristese. Mi ventura pasó y pasó el día, que clareava // la noche para mí si por dicha o caso bien te avía. ¡O vos que me oís por mi scriptura! Si la sentís, ijuzgad la pena mía y conocet sin par mi desventura!

Música: Anónima.

18.

ff. $[9 v]-[10 r]$

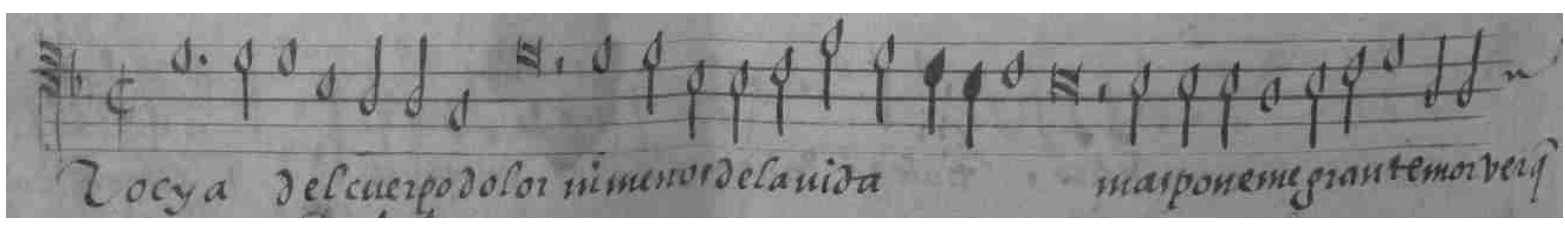

Poema: Anónimo.

No [h]e ya del cuerpo dolor, ni menos de la vida, mas póneme gran temor ver quell'alma, por amor, 


\section{FRANCESC VillaNUEVA SERRANO}

va también esser perdida.

No es mucho el cuerpo perderse

ni la vida, // que's mortal,

mas perder el principal

e ll'alma, que's inmortal,

eso es mucho de dolerse.

Ya yo triste no [h] e dolor

del cuerpo ni de la vida,

mas póneme gran temor

ver que ll'alma por amor

va también esser perdida.

Glosa anónima con pequeñas variantes y un verso menos en el Cancionero Sevillano de Toledo (Biblioteca de Castilla-La Mancha, fondo Borbón-Lorenzana, ms. 506, f. 390vb). Edición en Labrador, Difranco \& Montero, 2006, p. 386: "No é ya del cuerpo dolor, / ni muy menos de la vida, / mas póneme gran temor / ver que el alma, por amor, / va tanbién a ser perdida. / No es mucho el cuerpo perderse / ni la vida que's mortal, / mas perder lo prinçipal / esto es mucho de dolerse. / Ya yo triste no é dolor / del cuerpo ni de la vida, / mas póneme gran temor / ver que el alma, por amor, / va tanbién a ser perdida”. Dutton, 1990, vol. IV, p. 319, TP2-5, ID4329.

Música: Anónima.

Una pieza diferente con el mismo texto, aunque con motivos musicales que guardan cierta semejanza, es atribuida a [Rodrigo] “Ordóñez” en CMLG, ff. 10v-11r (Iglesias, 1996, pp. 450, 459).

19.

ff. $[10 \mathrm{r}]-[10 \mathrm{v}]$

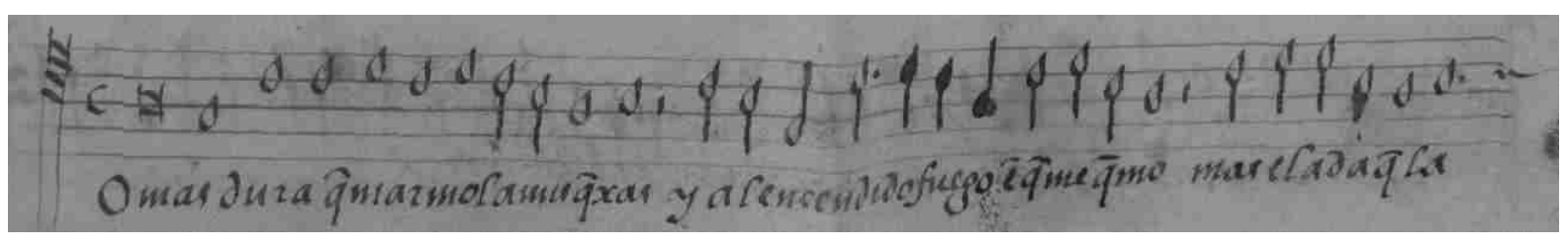

Poema: [Garcilaso de la Vega $(* 1499 ; \nmid 1536)]$.

O más dura que mármol a mis quexas $\mathrm{y}$ al encendido fuego en que me quemo;

Más elada que la nieve Galatea, estoy muriendo y aún la vida temo.

Témola con razón, pues tú me dexas; que no ay sin ti el bivir para que sea vergüença en que muera ninguno en tal estado.

De ti, desamparado, y de mí mismo, yo me corro agora. 


\section{El CANCIONERO MUSICAL DE GERONA:}

[D']un alma te desdeñas ser señora; donde sempre moraste, no pudiendo d'ella salir una ora.

¡Salid sin duelo lágrimas, corriendo!

Silva de Salicio en la Égloga al visorey de Nápoles (Égloga I). Publicada por vez primera en Boscán, 1543, f. 191r (edición en Vega, 2004, pp. 224-225).

Música: [Pedro Guerrero].

Pudo formar parte del impreso titulado Sonetos \& Madrigais dificiles. Pedro Guerrero, a 3 hoy considerado perdido (Iglesias, 1998, pp. 461-503).

Concordancias con:

- CMM, f. 67v-68r. A 4 voces. Atribuido a Pedro Guerrero. Edición en Querol Gavaldá, 1949, vol. I, nº6, pp. 18, 50 (estudio), 112-116 (edición). La parte del CMG se corresponde con la etiquetada como "tenor".

- Fuenllana, 1554, f. 123v-124v. Brown, 2000, no15543. Lesure, 1960, no155432. Primera parte del madrigal. Atribuido a Pedro Guerrero. En el Cancioneiro Musical de Belem, ff. 72v-73r se conserva una pieza a 3 voces de autor anónimo con el mismo texto aunque con distinta música (edición en Morais, 1988, pp. 47, 89-91). En E- $V$, ms. 17, ff. 80v-82r se conserva la parte de tenor de otra pieza a 5 voces con el mismo título atribuida a "Julio Severino" (Anglés, 1948, p. 84; López-Calo, 2008, p. 192).

20.

f. $[11 \mathrm{r}]$

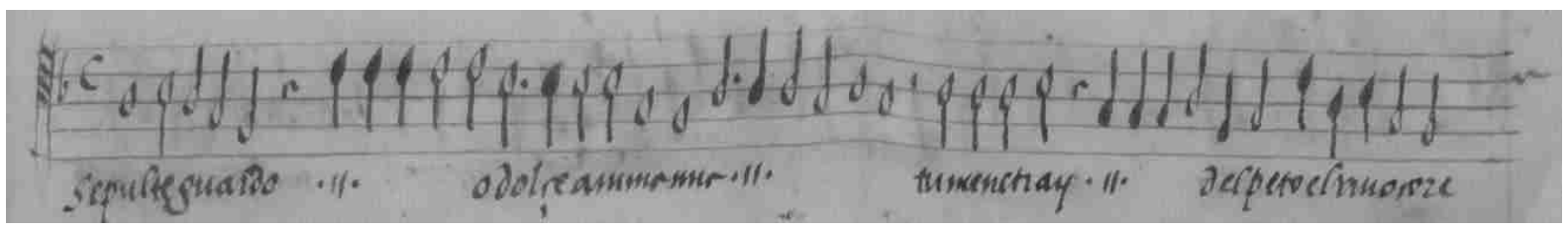

Poema: Anónimo.

Se pur te guardo, o dolce anima mia, tu me ne tray del peto el vivo core.

Caro tesoro, viso mio bello,

De[h]! non me dar tanto martelo,

Yo son pur tu servitore.

$\mathrm{De}[\mathrm{h}]$ ! non me far morir,

o dolce anima mia.

Música: [Adrian Willaert?; Rogier Pathie?]. 


\section{FRANCESC VillaNUEVA SERRANO}

Concordancias con:

- Rotta, 1546, ff. 44v-45v. Versión en tablatura italiana de laüd. Brown, 2000, n¹54615. Lesure, $1960, \mathrm{n}^{\circ} 1546^{33}$.

- Valderrábano, 1547, ff. 33r-33v. Versión para canto y vihuela en tablatura. Brown, 2000, n⿳15475. Lesure, 1960, $\mathrm{n}^{\circ} 1547^{25}$.

- Donato, 1550, p. 12. RISM, 2021, ID obra no00000993108717. RISM, 2021, [1550c]/19. La colección fue reeditada por el mismo impresor en 1552, 1554 y 1558 (Lewis, 2005, p. 102).

- PL-GD, Ms 4003 (solo S,A,B). Atribuido a "Adrianus Vuillart" [Adrian Willaert]. Datado en 1550-1599 (RISM, 2021, ID colección n³05000781; obra n³05000856).

- S-Sk, S 229: 1-2 (solo S2). Datado en 1550-1599 (RISM, 2021, ID obra n¹90014723).

- Varios, 1552, p. 34. Versión en tablatura francesa de laúd. Brown, 2000, n¹55211. Lesure, $1960, \mathrm{n}^{\circ} 1552^{29}$.

- Varios, 1553, f. B4r. Versión para canto y laúd en tablatura francesa. Atribuida a “Rogier" [Roger Pathie?]. Brown, 2000, n¹55310. Lesure, 1960, n¹55333.

- DK-Kk, R151-155, ff. 43r (Sextus), 99v (Tenor), 114v (Quintus). Datado por RISM en 1556c (RISM, 2021, ID colección n¹50203016; obra n¹50202984).

- Ochsenkhun, 1558, f. 85v. Versión en tablatura alemana de laúd. Brown, 2000, $\mathrm{n}^{\mathrm{o}} 1558_{5}$. Lesure, $1960,1558^{20}$.

- Gorzanis, 1563, p. 60. Versión en tablatura italiana de laúd. Brown, 2000, n¹5638.

- Varios, 1563, f. 37r. Versión en tablatura francesa de laúd. Brown, 2000, n¹56312.

- Vreedman, 1568, ff. 24r-25r. Brown, 2000, n¹5686. Lesure, 1960, nº156824.

- Varios, 1568, f. 26r. Versión en tablatura francesa de laúd. Brown, 2000, n¹5687. Lesure, $1960, \mathrm{n}^{\circ} 1568^{23}$.

- Hortulus cytharae, in duos distinctos libros, quorum prior cantiones musicas longe pulcherrimas, passomezo, paduanas, galliardes, alemandes, branles, ad usum vulgaris cythara, Lovaina, Pierre Phalèse y Jean Bellère, 1570, ff. 81v-82r. Versión en tablatura francesa de guitarra. Brown, 15703. Lesure, $1960,1570^{34}$.

- Varios, 1571, f. 58r. Versión en tablatura francesa de laúd. Brown, 2000, 15716. Lesure, $1960, \mathrm{n}^{\circ} 15711^{16}$.

- Ammerbach, 1571, f. B3v, 19v. Versión en tablatura alemana de tecla bajo el título Allein nach dir Herr Jhesu Christ verlanget. Brown, 2000, n¹571 . Lesure, 1960, $15711^{17}$.

- Varios, 1572, f. B1v. Versión en tablatura alemana de laúd. Brown, 2000, n¹572. Lesure, $1960, \mathrm{n}^{\circ} 1572^{12}$.

- Waissel, 1573, f. C4r. Versión en tablatura alemana de laúd. Brown, 2000, n¹573 3. Lesure, $1960, \mathrm{n}^{\circ} 1573^{27}$.

- Varios, 1574, ff. 46v-47r. Versión en tablatura francesa de laúd. Brown, 2000, n¹5747. Lesure, $1960, \mathrm{n}^{\circ} 1574^{12}$. 


\section{El CANCIONERO MUSICAL DE GERONA:}

MADRIGALES Y VILLANCICOS EN UNA NUEVA FUENTE HISPÁNICA DEL SIGLO XVI

- Schmid, 1577, ff. V2v-V3v. Versión en tablatura alemana de tecla. Brown, 2000, $\mathrm{n}^{\circ} 1577$. Lesure, 1960, nº157712.

- Kargel, 1578, f. E2v. Versión en tablatura francesa de guitarra de cuatro cuerdas. Brown, 2000, $\mathrm{n}^{\circ} 1578_{4}$. Lesure, 1960, $\mathrm{n}^{\circ} 1578^{25}$.

- Varios, 1582, ff. 11v-12r. Versión en tablatura francesa de guitarra de cuatro cuerdas. Brown, 2000, nº1582. Lesure, 1960, $\mathrm{n}^{\circ} 1582^{16}$.

- Ammerbach, 1583, pp. 73-74. Versión en tablatura alemana de tecla bajo el título Allein nach dir Herr. Brown, 2000, nº15832. Lesure, 1960, nº158322.

- NL-Uu, ms.L.16, ff. 26v-27r (Codex Lerma). Versión para ministriles. Datado en 15901600 (Kirk, 2006, p. xvi).

- D-Mbs, Mus., ms. 4748, f. 87v. Versión en tablatura alemana de tecla. Datado en 1602 (RISM, 2021, ID obra nº1001011453).

21.

ff. $[11 \mathrm{r}]-[11 \mathrm{v}]$

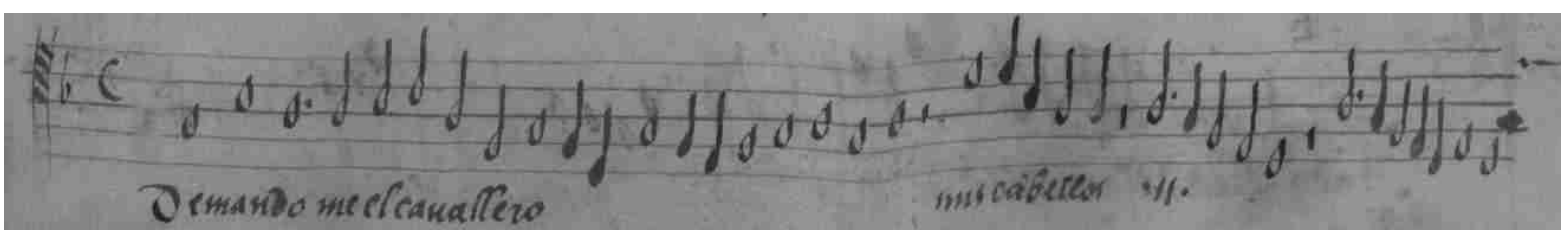

Poema: Anónimo.

Demandome el caballero

mis cabellos,

y a mí con ellos;

Madre, non cavallero,

non de Aragón

demándame mis cabellos

para mi cordón,

y a mí con ellos.

Música: Anónima. 
22.

ff. $[11 \mathrm{v}]-[12 \mathrm{r}]$

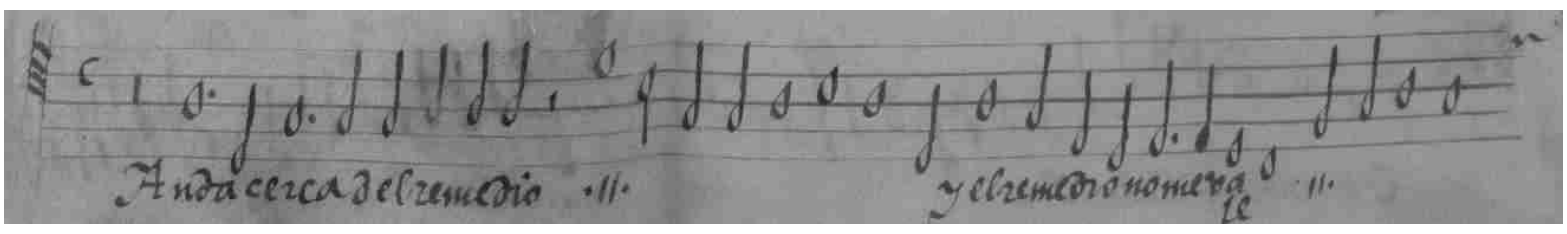

Poema: Anónimo.
Anda cerca del remedio y el remedio no me vale. ¡Ay, que ll'alma se me salle! ¿Qué remedio puede ser remedio que no provecha? [...] flecha que d'aumento [e]s padecer.

Música: Anónima.

Anotación: “a $\cdot 5 \cdot \operatorname{vo}[\mathrm{ces}]$ ”.

23.

f. $[12 v]$

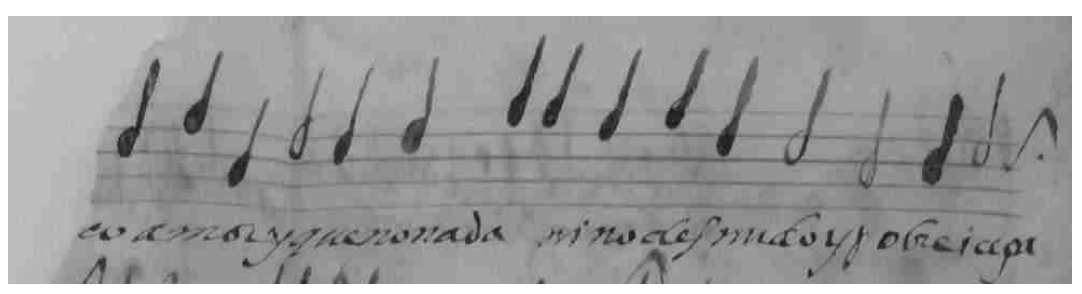

Poema: Anónimo.

$[\ldots]$ co amor y que no nada sino desnudo y pobre i cepa[...] ni bellicoso.

Música: Anónima. 